Article

\title{
The New Holistic Paradigm and the Sustainability of Historic Cities in Spain: An Approach Based on the World Heritage Cities
}

\author{
Joaquín Martínez Pino \\ Department of Art History, Geography and History Faculty, Universidad Nacional de Educación a \\ Distancia (UNED), C/Senda del Rey, 7, 28040 Madrid, Spain; jmpino@geo.uned.es; Tel.: +34-913-987881
}

Received: 14 May 2018; Accepted: 29 June 2018; Published: 3 July 2018

check for updates

\begin{abstract}
Linked to the objectives of sustainability of the United Nations, the reflection on the historic city promoted by UNESCO has favored the emergence of a new holistic paradigm that focuses on the capacity of culture to improve the quality of life of people and seeks to recover the historical link among culture, development and sustainability. Based on this context, this paper analyzes the main problems that face Spanish World Heritage Cities in terms of sustainability and livability, and the correlation between the new paradigm and the reality of its current management. This study explored sustainability indicators based on the evolution of the population and the number of visitors. The current protection and management model is reviewed based on the four basic tools identified by UNESCO: Regulatory systems, Knowledge and Planning tools, Financial tools and Civic engagement tools. The joint analysis of UNESCO's Periodic Reports allows us to identify the shortcomings that point to a disconnection between heritage city management and citizenship. After analyzing the impact of the new paradigm in the Spanish reality, the need to continue deepening its dissemination and accelerating its implementation is evident. In the same way. it is essential to establish and implement models of citizen participation that favor the fulfillment of the sustainability challenges of historic cities.
\end{abstract}

Keywords: Spain; world heritage cities; sustainability; holistic paradigm; historic urban landscape; living heritage; culture; community; tourism

\section{Introduction}

Since the mid-twentieth century, historic cities in Spain have faced profound functional and social changes that test the ability to combine the maintenance of old physical structures with new socio-economic and cultural realities. As Trotiño has pointed out, the historic city is having trouble finding the balance between the old and the new, between the city of progress and the city of culture [1]. The urban recovery of historic centers has in many cases put aside the sociocultural and functional dimensions in favor of policies that have taken precedence over the physical conservation of historical heritage and have fostered an economy based almost exclusively on tourism. Tourism has become the main engine of the Spanish national economy. The statistics estimate its contribution to the GDP around $11.2 \%$ at the beginning of 2017, equaling and even exceeding those prior to the crisis [2]. Considering the historical center as a reality apart from changes in functionalities and urban and territorial structure has been one of the greatest limitations of the last few years in Spain [3].

From the point of view of its management, the challenges facing cities in the 21st century are testing the limits and adequacy of existing tools. The conservation of urban heritage cannot be based on the delimitation of "sealed" spaces that are far from reality; what in many cases has been valid for singular monuments or archaeological areas does not work "for a living open system like a city, 
no matter how historic and protected" [4]. In terms of sustainability, what are at stake fundamentally are the values associated with the day to day of these spaces, the relationship between the historical city and citizenship. These issues are linked to phenomena such as the museumification of the historic city, the tertiarization of its economy, changes or residential underutilization or the loss of social life.

In recent years, UNESCO has worked with the objective of placing culture at the heart of the local development agenda, devoting important efforts to conceptualize a holistic approach to the city that has resulted in initiatives as important as the Recommendation on Historic Urban Landscapes of 2011 [5]. As Bandarin pointed out, "many reasons support the need to review the present urban conservation paradigm. Some are linked to the transformation of the concepts and approaches to heritage conservation; others derive from the challenges and pressures originated by the processes of global exchange and by the changing uses of historic cities [6] (p. 215)." The new paradigm promoted by UNESCO is in line with the objectives on the sustainability of cities, adopted by the United Nations (Goal 11 of the 2030 Agenda for Sustainable Development, Paris, 2015) [7], and with the New Urban Agenda, Habitat III, of the UN Conference on Housing and Sustainable Development (Ecuador, 2016) [8]. Conserving and managing in this context requires "creativity and ingenuity, jointly with an approach free from dogmatic attachment to the important-albeit now inadequate-set of principles and a toolbox inherited from the twentieth century [6] (pp. 220-221)." In accordance with these same challenges, the studies on cultural heritage have been expanding their scope for years, to offer diagnoses that respond to a necessary interdisciplinary and holistic view.

The objective of this article is to compare the policies of protection and management of historic cities in Spain with the new holistic paradigm established by UNESCO, while detecting possible shortcomings and pointing out the main measures to be implemented. To this end, the following issues are addressed:

- $\quad$ Principle problems and challenges of sustainability and livability that affect historic cities in Spain.

- Comparison of the model of protection and management of historic cities with the aims and tools of UNESCO's Recommendation on Historic Urban Landscape.

\section{The Construct of a New Holistic Paradigm. International Framework}

In the international arena, the reflection on cities and historic centers took a leading role in the 1970s, strongly driven by the approval of the 1972 World Heritage Convention and the designations of the first cities and urban areas as World Heritage Sites. In 1976, the Nairobi Recommendations Concerning the Safeguarding and Contemporary Role of Historic Areas, represented an important advance in the recognition of the constitutive elements of historical spaces and in the adoption of policies for their preservation. The spirit of this movement is exemplified by the identification of historical areas as the place where the past is manifested and which mark the cultural diversity and the identity of a society. This also included the call to consider historical areas and their bordering spaces as a whole, or the consideration of the character of these spaces and traditional, social and economic structures as elements linked to architectural conservation.

Some years later, the Washington Charter of 1987 provided the necessary complement to the Venice Charter of 1964. One of the most novel aspects was its definition of "authenticity", applied not only to the physical elements but also to the relations between the urban area and its surroundings, or the various functions acquired by these areas over the course of history [9]. In 1994, The Nara Document on Authenticity dealt with the impossibility of establishing fixed criteria on the idea of authenticity, calling to accept cultural diversity as an element that must be preserved and recognized. These precedents illustrate a change of focus in the identification and preservation of patrimonial values, which shifts from the focus on the physical object to the immaterial aspects linked to these manifestations. The Convention for the Safeguarding of the Intangible Cultural Heritage (2003) and the Convention on the Protection and Promotion of the Diversity of Cultural Expressions (2005) contribute significantly to the new conceptual framework. Applied to the city and historical sites, the Burra Charter [10] promises the assessment of the significance of a place as a basis for developing 
conservation and management strategies-based on the values attributed by all stakeholders (not only by the experts) and the use of a Statement of Significance [11].

In Vienna, in 2005, UNESCO's conference “World Heritage and Contemporary Architecture-Managing the Historic Urban Landscape" discussed contemporary transformations in historic cities and the limitations of existing tools-borders and buffer zones-to deal with the visual impact on properties designated to be World Heritage Sites. As a result, the "Vienna Memorandum on World Heritage and Contemporary Architecture" introduced the notion of the historic urban landscape as a tool to reinterpret the values of urban heritage [12]. The Memorandum reflected a change towards sustainable development in the governance of historic sites, as well as a broader vision of the nature of urban heritage [6] (p. 219). The Vienna Conference opened the door to a long debate both in UNESCO headquarters and in ICOMOS, inspiring numerous seminars, meetings and assemblies of a regional and general nature that took place between 2005 and 2011-including two General Assemblies of ICOMOS, held in Xi' an (2005) and Quebec (2009) — that highlighted the complexity of values, both material and immaterial, associated with certain spaces, the importance of perceptive processes in the identification of cultural heritage and the need to develop new strategies and tools for their conservation and management.

UNESCO's Recommendation on the Historic Urban Landscape (HUL), adopted on November 10th, 2011, was created with the aim of providing updated guidelines and tools for the management of historic cities, with the central element being the preservation and sustainability of their cultural value. Its principal novelty was the adoption of a landscape view of the interpretation and management of the various cultural values that occur in the city. It is a view that is contextual, holistic and dynamic. "Urban heritage values are directly linked to the spirit of place in the landscape because it is from the cultural landscape that the original canvas of urban form springs [13] (p. 163)." Thus, "historic urban landscape is the urban area understood as the result of a historic layering of cultural and natural values and attributes, extending beyond the notion of 'historic centre' or 'ensemble' to include the broader urban context and its geographical setting" (I.8 HUL Reccomendation [5]). However, beyond the adoption of a landscape view, what is interesting in this study is that the application of the historic urban landscape implies the development and use of the following tools adapted to local contexts (IV.24 of HUL Recommendation):

- $\quad$ Regulatory systems encompass legislative and regulatory measures aimed at the conservation and management of the tangible and intangible attributes of the urban heritage.

- Knowledge and planning tools are created to protect the integrity and authenticity of the attributes of urban heritage. They should also allow for the recognition of cultural significance and diversity, and provide for the monitoring and management of change to improve the quality of life and the urban space.

- Financial tools are aimed at building capacities and supporting innovative income-generating development rooted in tradition.

- Civic engagement tools empower a diverse cross-section of stakeholders to identify key values in urban areas and develop plans to safeguard their heritage and promote sustainable development.

At the meeting of experts in World Heritage (Rio de Janeiro, 2013), it was reiterated that the Recommendation on Historic Urban Landscape is applicable to any urban environment, not only for cities designated World Heritage Sites. The meetings of the World Heritage Committee of Doha (2014) and Bonn (2015) underscored the importance of deepening the implementation of sustainable development measures contained in the Recommendation. Even the 38th session of the General Conference of UNESCO (2015) included a positive report on the application of the Recommendation, mainly in the regions of Asia, Africa, Latin America and the Caribbean, encouraging all member states to apply the Recommendation in the context of the 2030 Agenda for Sustainable Development [14].

Gustavo Araoz, President of the International Council of Monuments and Sites (ICOMOS) underlines this crucial moment by remembering that even in the western world, "the values of 
traditional heritage no longer reside exclusively on its physical fabric and form [ ... ] In contrast to traditional practice, the values of the emerging heritage paradigm most often rest on intangible vessels, for which the existing conservation toolkit is of little assistance [15] (pp. 58-59)." The experience gained from pilot initiatives developed in different cities around the world has recently been collected in "The HUL Guidebook" (2016) [16]. The Global Observatory on the Historic Urban Landscape (GO-HUL) offers a collaborative space between cities working on the implementation of HUL-based projects, in which to share resources, activities and outcomes [17].

Finally, one of the elements that best characterizes this paradigm shift is the attention to the role of communities in the identification and management of cultural heritage. This is highlighted by programs such as those developed by ICCROM, with the titles People-Centred Approach or Living Heritage, whose main objective is to definitively break with the old consideration of heritage as an isolated entity that requires resources for its conservation and management, and rather recognize the potential influence of the heritage to play an active role in communities and bring benefits to people $[18,19]$. To this end, the role of the community and the importance of involving it in the preservation and management of its heritage is a central element [20]. Recently, the 19th General Assembly of ICOMOS (Delhi 2017) ratified the validity and relevance of the new paradigm, highlighting concepts already mentioned-including that "Cultural Heritage and Democracy means a people-based approach;" that "cultural heritage constitutes a key resource in enhancing livability and fosters economic development and social cohesion in a fast-changing global environment;" and the recognition of "everyone's right to determine their cultural heritage and participate in the decision-making and management processes as fundamental democratic rights" [21].

\section{Materials and Methods}

The UNESCO-World Heritage Center (WHC) includes in its World Heritage List a total of 14 designations with the criteria of "Cities" in Spain, which actually affects 15 cities, by the joint designation of Úbeda and Baeza (Table 1). The Spanish World Heritage Cities (SWHC) constitute the sample on which this research is carried out. SWHC are the result of a long process of historical layering, often with the common root of Roman civilization, the whole series of elements and public spaces on which the idea of civitas is based (forums, temples, markets, bathrooms, walls, etc.).

Table 1. SWHC and the year of their inscription.

\begin{tabular}{cc}
\hline SWHC & Date of Inscription \\
\hline Granada, Alhambra, Generalife and Albaicín neighborhood & 1984 . Extension: 1994 \\
Cordoba, Mosque-cathedral and historic center & 1984 . Extension: 1994 \\
Ávila, Old City and extramural churches & 1985 \\
Santiago de Compostela, Old City & 1985 \\
Segovia, Old City and Aqueduct & 1985 \\
Cáceres, Old City & 1986 \\
Toledo, Historical City & 1986 \\
Cuenca, Historic Walled City & 1996 \\
Alcalá de Henares, University and Historical Site & 1998 \\
Salamanca, Old City & 1998 \\
Ibiza, Biodiversity and Culture & 1999 \\
San Cristóbal de la Laguna & 1999 \\
Aranjuez, Cultural Landscape & 2001 \\
\hline Úbeda and Baeza, Renaissance Monumental Ensemble & 2003 \\
\hline
\end{tabular}

Based on UNESCO's World Heritage List.

This study carried out a qualitative analysis of the data in the different sections in which it is divided. The following methodological steps were followed. 
Step 1:

The approach to the problems and challenges of the SWHC in terms of sustainability and livability was conducted by combining the review of the scientific literature with the analysis of quantitative population and tourism data. In this section, $\mathrm{n}$ a SWHC review is adopted based on two sustainability indicators shown by the Andalusian Cultural Heritage Institute [22] (pp. 222-226):

1. Evolution of the population.

2. Number of visitors in relation to the resident population.

Considering the peculiarities of SWHC, in which there is a designated area differentiated both in terms of morphology and in terms of protection or activity regime, a variable was introduced on these indicators that for this work was considered fundamental: the differentiation between designated area and unprotected area of the city, according to the dynamics observed by Asworth and Tunbridge [23]. This variable was intended to identify phenomena such as the depopulation of such areas, whose evolution sometimes follows different trends to the rest of the city.

To obtain the population data, a request was made to the offices of the Municipal Register (Municipal Registers of Inhabitants) of the different heritage cities and the National Institute of Statistics (INE). The responses were disparate, so only cases with first-hand data were analyzed.

Step 2:

The adequacy of the protection and management model of SWHC with respect to the new holistic paradigm was made by comparing the Spanish model with the four areas indicated by UNESCO in the Recommendation on Historic Urban Landscape. It was a task of great complexity, due to the varying factors that come into play and the difficulty in issuing indisputable judgments about the adaptation of the conservation and management policies of Spanish cities to the new paradigm. One of the aspects to take into account was that, in many cases, the existence of documents and management plans does not always translate into an effective application of them.

The tools used $\backslash$ to analyze the Spanish model ere those used by UNESCO-WHC to evaluate the state of the properties designated World Heritage:

1. Reports prepared for UNESCO-WHC by the States Parties, on the properties designated before 2007, which must be approved by the World Heritage Committee with the help of its Advisory Bodies (Decision 31 COM 11D.1).

2. Periodic Reports, much richer in information, designed by UNESCO-WHC in accordance with Art. 29 of the World Heritage Convention of 1972, with the aim of evaluating its correct application by the States Parties, and developing more sustainable conservation mechanisms for their World Heritage properties.

The Periodic Reports are carried out every six years and are based on the completion of an online questionnaire [24], according to the instructions and indications given from UNESCO-WHC, in which the National Focus Point (in the Spanish case, the Ministry of Education, Culture and Sport) and the different Site Managers are involved. The National Focus Point and the Site Managers have specific training programs and tools at their disposal (Meetings, Tutorials, FAQs [25] and a Handbook for Site Managers [26]). Each Site Manager is responsible for completing Section II of the questionnaire for their respective site, while the National Focus Point is responsible for the completion of Section I and for validating Section II of the questionnaire after completion by the respective Site Managers.

This study focused on the results of the Second Cycle of Periodic Reporting (2008-2015) launched at the 36th session of the World Heritage Committee (Saint Petersburg, 2012) (Decision 36 COM 10B). Scope, structure, implementation strategies, and methodology of Periodic Reporting can be consulted in document WHC-15/39.COM/10A [27]. The questionnaire is a self-assessment exercise, on which UNESCO-WHC guarantees, for analytical purposes, the reliability and validity of the data and conclusions drawn from them [27] (p. 14). With the objective of evaluating the operation and adaptation 
of the questionnaire, a Periodic Reporting Reflection Survey invited States Parties to comment on various elements of the Periodic Reporting exercise, including the process, format, use and analysis of data, relevance and efficiency. In this sense, the results for the period 2008-2015 indicate that, throughout the world, $82 \%$ of the States Parties stated that their national authority' focal points for World Heritage were given sufficient training and guidance to fill in the Periodic Reporting Questionnaire by the World Heritage Centre [28].

For the objective of this study on SWHC, a selection of questions and answers of Section II of the Questionnaire were considered. All the Periodic Reports that were consulted are available on the UNESCO-WHC website, as documents of the World Heritage List. The results and the graphs presented below were created by the author based on the sharing of the responses made by the Site Managers of the different SWHC. Quantitative data were obtained from this process that allowed us to measure the degree of generalization of the problems detected.

\section{Analysis of Data and Results}

\subsection{Problems and Challenges of Sustainability and Livability in SWHC}

"There will be no urban future-less so sustainable urban development-without a full understanding of the power of culture in addressing the social needs of city dwellers and their aspirations to a better quality of life [29] (p. 17)". However, in the current context, culture and historical heritage in cities must also face important challenges: urban pressure, fragmentation and commercialization of historical centers, gentrification and suburbanization, architectural uniformity or changes in lifestyles and socialization, urban development's incompatibility with the historical character of the city, mass tourism, etc.

In the case of Spain, the problem is varied and manifests itself with greater or lesser clarity depending on the size of the cities, their ability to attract residents, their economic vitality and their cultural attractiveness. Gentrification processes are already evident in the historic centers of large cities such as Madrid and Barcelona, for example, where the prices of the real estate market grow more than the acquisition capacity of the population, and holiday homes (managed through platforms such as Airbnb or Homeaway) already exceed the number of places offered by hotels [30]. The phenomenon, linked to the pressure of tourism, is rupturing the balance in certain neighborhoods and causing an increasingly evident conflict. In Barcelona, tourism was already the main problem in the opinion of its inhabitants in the middle of last year, giving rise to the generalization of a new term, "turismofobia" or "touristphobia" [31,32]. Meanwhile, a large part of the historic centers of small- and medium-sized cities face progressive aging and depopulation, a process mitigated during the first years of the century with the arrival of immigrant populations, but which has accelerated again as a result of the economic crisis of the last decade. The latest projections from the National Statistics Institute of Spain (INE) predict, if the current trend continues, the loss in the next 15 years of half a million inhabitants, and 5 million in 50 years. The population of inhabitants 65 years and older, which currently stands at $18.7 \%$ of the total population, would become $25.6 \%$ in 2031 , and $34.6 \%$ in 2066 [33].

The sustainability of historic cities in Spain has been the subject, in recent decades, of numerous studies. Troitiño Vinuesa, García Hernandez, Lara y López or De la Calle Vaquero allow us to understand, from different case studies, the impact of tourism on historic cities and their economic development [34-41]. On the other hand, among the aspects approached from the patrimonial literature, authenticity, trivialization and the commodification of heritage have constituted the points of greatest interest, demonstrating the existence of a logic of consumption that threatens the balance between patrimony, citizenship and tourism at the physical level as symbolic [42-44]. The tourist phenomenon has a particular effect on historical centers as opposed to the rest of the city [23], so it is important to try to read their specific dynamics. In this line, studies on load capacity in monumental cities of García Hernandez or De la Calle-Vaquero [39,41] are important. 
As some experts have pointed out, commercial activity in the urban fabric is directly related to the revitalization or decay of certain areas. "The thematization provoked by excessive and poorly planned tourist activity, the substitution of traditional businesses for more profitable ones (financial sector, cabinets and studies of liberal professionals, franchises [...], the relocation of businesses with the consequent abandonment of buildings and the decrease of the quality of life in the center due to lack of activity [...] are recent problems that are distorting the values that traditional commercial activity had transferred to the historic center [45] (p. 76)." This is the field that is most in need of the collection of data by the administrations or organizations concerned. In too many cases, it can hardly support with statistics what in many historical centers is a palpable reality when walking its streets, despite some recent works in this line [46].

While in the international arena the construction of models for the evaluation of sustainability in historic cities has important examples, linked to the capacity of reception in tourist destinations [47], in terms of livability and sustainability the identification or construction of indicators on cultural heritage is a recently developed field in Spain. Having said that, there exists an important study done by the Andalusian Historical Heritage Institute in collaboration with the WHC [22,48]. Following the Compendium of Indicators prepared by this institution, this study focuses on:

1. An indicator of population and quality of life: evolution of the resident population; differentiating between the declared area and the rest of the city.

2. An indicator of economic activities: number of visitors in relation to the population residing in the declared historical center.

The monitoring of a population's growth in the SWHC is faced, first, with a stumbling block that is observed in all cases: there are no records specifically delineated to the areas affected by the designations of World Heritage. The population registers are built based on districts and sections whose correspondence with historical centers and World Heritage areas is very inconsistent. There are cases in which there is great approximation, for example, in Toledo, Cuenca and Segovia. In other cases, the city centers, by their structure, can be divided into several districts whose reach goes beyond the historical area, as in the case of Úbeda. In cities such as Santiago de Compostela or La Laguna it has been necessary to filter the results by streets, which introduces a margin of error because of the bordering streets that have houses both within and outside of the heritage area. In other cases, the information provided by some municipalities was collected exclusively through total population data, without the possibility of differentiating the growth of historic centers with respect to expansion areas, rendering it useless for the purpose of this work. Finally, important differences are found in the range of dates collected, since the record-keeping of inhabitants requires statistical procedures only established in the last decades.

Thus, the available information has not allowed for an accurate show of population growth in all cases. However, there are enough examples that illustrate a variable reality among the different SWHC, from which it is concluded that the UNESCO designation is not a factor that determines a population growth or loss, but that it is linked with a variety of factors including geographical conditions and topography, the existence of historically established expansion areas, or the structural systems between them and the historical area, with special attention regarding mobility.

Examples of SWHC with a clear problem of depopulation of the historic center are Toledo, Cuenca or Ávila. In 1986, the date of its being declared a World Heritage Site, Toledo had a total of 58,198 inhabitants, of whom 13,599 lived within the declared area. In 2016, residents in the historic center were numbered at 10,447-about 3000 fewer people-while the total number of inhabitants had grown to 83,619 . Thus, the ratio of population living in the historic center to the total has decreased from $23.36 \%$ in 1986 to $12.49 \%$ in 2016 [49] (Figure 1). In the case of Cuenca, the records of Districts 1 and 2-corresponding roughly to the declared area-between the year 2000 and 2016 reveal a very similar trend. While in the year 2000 the inhabitants in the historic center measured at 3344 for a total population of 44,585, in 2016 the ratio was 3029 citizens in the historic center to a total population 
of 77,408; a drop from the initial percentage of $7.5 \%$ to $3.9 \%$ [50]. These are figures that perfectly exemplify the decreasing prominence of the inhabitants of the historic center compared to those of other areas, which undoubtedly results in less attention to their needs and impoverishment of services, as recently some of these residents reported to the press [51].

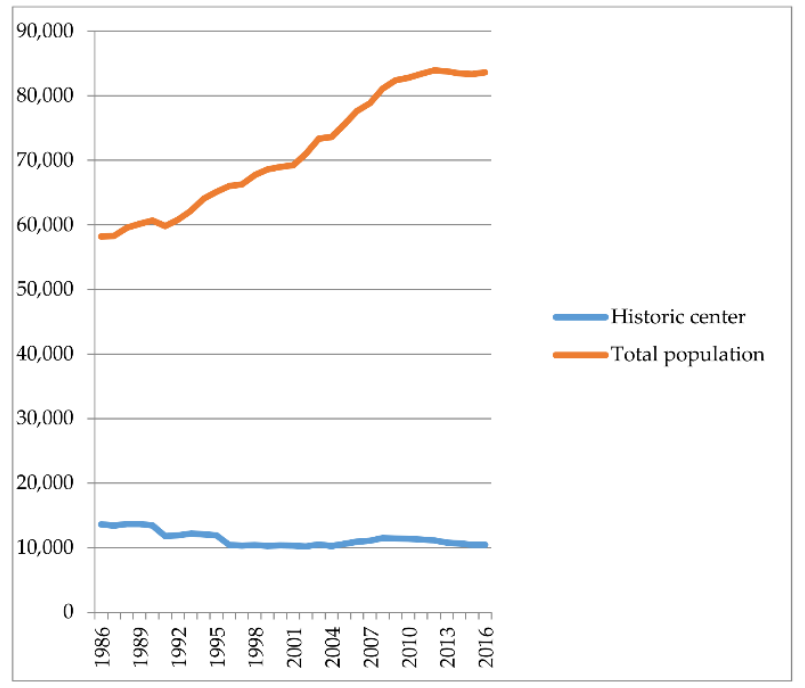

Figure 1. Population evolution in Toledo, 1986-2016. Historic center versus total population.

In Ávila, the historical center-walled area and surrounding medieval neighborhoods-testifies to a continuous reduction in the number of residents. According to Martínez Fernandez, the 2004-2012 report indicates that 6139 people lived in the medieval area (10.5\% of all the inhabitants of the province of Ávila), reducing by 533 in 2014 [52]. A decline that, according to the technical office of the population register, has continued over time, although there are no precise data on the World Heritage area [53]. A residential emptying in which the absence of free spaces, the difficulties for the replacement or renovation of old houses, or the insufficiency of infrastructures and services, are the most argued explanations. Therefore, the population is considered scarce and aging compared to the rest of the city, according to the Ávila Diagnostic included in its recent Management Plan [54] (pp. 15-17).

Cities such as Segovia and Santiago de Compostela exhibit some intermediate results. In Segovia, District 1 is undergoing a slight but continuous decline since 2000, moving from 4325 inhabitants to 3928 in 2012, and to 3609 in 2017; all this with a total population that increased slightly between 2000 and 2012-from 54,483 to 54,936-and dropped in 2017 to 52,170 inhabitants [55]. Santiago de Compostela moves within similar figures; in 1996 with a reported 6502 inhabitants in the historic center out of the 93,672 total population, and currently with 5913 historic center inhabitants for a total population of 96,456; percentages that drop from the initial $6.9 \%$ to the current $6.1 \%$ [56].

On the contrary, some cities can be found in an ascending line regarding the population of historic centers, such as La Laguna, where the increase went from 5126 inhabitants in 1997 to the current 5920 [57]. This is a particular case that should be understood in a context of the strong demographic growth that characterizes the Canary Islands, which is much more pronounced than in the rest of the country. Thus, in 2010, the population growth of La Laguna in the last 20 years was around 40\% [58]. In La Laguna the zone called "Casco" - that includes the world heritage area-was the most populated, with 32,107 inhabitants in 2015, which constituted $21 \%$ of the total population [59] (p. 110).

In relation to the evolution of tourism, the good momentum that the Spanish tourism industry is currently experiencing has already highlighted, closing the year 2017 with 82 million foreign visitors $-8.9 \%$ more than in 2016-becoming the country with the second-highest number of visitors, surpassing the US and trailing only France [60]. These are statistics that are also in accordance with the SWHC, which have followed the general guideline, also setting records for number of travelers 
staying and overnight stays. In Table 2, this evolution is observed in six-year stretches since 2005, the date in which the first data are recorded by tourist points, until the end of 2017. Note, first, that this statistic does not include data on world heritage cities such as Aranjuez, Ibiza, Ubeda, Baeza, Alcalá de Henares or La Laguna. In addition, note the fall in the number of visitors that occurs in 2011-2012 in some SWHC of the interior, whose cause is undoubtedly linked to the strong economic crisis during these years.

Table 2. Number of overnight stays in SWHC. December-November/2005-2011-2016.

\begin{tabular}{cccc}
\hline SWHC & $\begin{array}{c}\text { December } \\
\text { 2005-November 2006 }\end{array}$ & $\begin{array}{c}\text { December } \\
\text { 2011-November 2012 }\end{array}$ & $\begin{array}{c}\text { December } \\
\text { 2016-November 2017 }\end{array}$ \\
\hline Ávila & $359, \mathbf{1 9 9}$ & 303,646 & 440,868 \\
Cáceres & 369,856 & 361,682 & 438,598 \\
Córdoba & $1,143,786$ & $1,295,184$ & $1,615,097$ \\
Cuenca & 340,508 & 275,153 & 334,206 \\
Granada & $2,532,495$ & $2,622,978$ & $3,253,226$ \\
Salamanca & 984,313 & 917,865 & $1,097,193$ \\
Santiago de Compostela & $1,031,938$ & $1,071,023$ & $1,448,454$ \\
Segovia & 273,332 & 308,098 & 467,643 \\
Toledo & 725,755 & 703,443 & 914,034 \\
\hline
\end{tabular}

Own elaboration based on the INE's Hotel occupation survey. http:/ / www.ine.es/jaxiT3/Tabla.htm?t=2078\&L=0.

The exercise of cross-referencing the population data with the tourism data provided by the INE, was only possible with a portion of the SWHC. In the examples below, the evolution of the number of visitors in relation to the resident population in SWHC can be observed (Table 3).

Table 3. Ratio of tourists/inhabitants in SWHC. December-November/2005-2011-2016.

\begin{tabular}{cccccccccc}
\hline \multirow{2}{*}{ SWHC } & \multicolumn{3}{c}{ Inhabitants in Historic Center } & \multicolumn{3}{c}{ Tourists, $\boldsymbol{n}$. of Overnight Stays } & \multicolumn{3}{c}{ Ratio of Tourists/Inhabitants } \\
\cline { 2 - 11 } & $\mathbf{2 0 0 5}$ & $\mathbf{2 0 1 1}$ & $\mathbf{2 0 1 6}$ & $\mathbf{2 0 0 5}$ & $\mathbf{2 0 1 1}$ & $\mathbf{2 0 1 6}$ & $\mathbf{2 0 0 5}$ & $\mathbf{2 0 1 1}$ & $\mathbf{2 0 1 6}$ \\
\hline Cuenca & 3493 & 3339 & 3029 & 340,508 & 275,153 & 334,206 & 97 & 82 & 110 \\
Santiago de & 5752 & 6373 & 5982 & $1,031,938$ & $1,071,023$ & $1,448,454$ & 179 & 168 & 242 \\
Compostela & & & & & & & & & \\
Segovia & 4209 & 4041 & 3609 & 273,332 & 308,098 & 467,643 & 65 & 76 & 130 \\
$\quad$ Toledo & 10,600 & 11,275 & 10,447 & 725,755 & 703,443 & 914,034 & 68 & 62 & 87 \\
\hline
\end{tabular}

Own elaboration based on the INE's Hotel occupation survey and population data.

As pointed out by García Hernandez, the different variables involved, the particularity of each case and the operational difficulties, make the studies on load capacity and the reading of their results extremely complex. They require a qualitative interpretation involving value judgments [39] (pp. 82-83) On the other hand, cities such as Cuenca, Segovia or Toledo, close to and well connected to Madrid, are preferential targets for a single excursion day, and its quantification constitutes one of the major research problems and one of the greatest sources of uncertainty [39] (pp. 94-95). In any case, the results obtained do allow us to observe a trend of evolution of tourism in SWHC: that of a continuous growth that could not be maintained without definitively breaking the tourism-citizenship balance. The decreasing ratios among the number of inhabitants in historical centers with respect to the number of tourists show that the SWHC live in serious risk of becoming mere monumental sceneries for tourism, losing on the contrary a series of intangibles linked to their "spirit of place".

\subsection{Protection and Management Model of the SWHC in Relationship with the New Holistic Paradigm}

In general, Spanish cities enjoy good health in terms of the conservation of patrimonial values that granted them with World Heritage status. In 2005, the Operational Guidelines Document established that "to be deemed of Outstanding Universal Value, a property must also meet the conditions of 
integrity and/or authenticity and must have adequate protection and management systems to ensure its safeguarding" (Paragraphs 49, 78) [61], starting a review process for those properties designated before 2007. The Retrospective Statements of Outstanding Universal Value are reports prepared by the States Parties, which must be approved by the World Heritage Committee with the help of their Advisory Bodies (Decision 31 COM 11D.1). In the case of SWHC, this procedure has been included in documents WHC-14/38.COM/8E of April 2014, WHC-15/39.COM/8E.Rev of June 2015 and WHC/16/40.COM/8E.Rev of June 2016 (with the exception of Cuenca, Toledo and Ibiza). In all of them, the review reflects positive results.

The following is a structured analysis based on the four tools identified by UNESCO in its HUL Recommendation: Regulatory System, Knowledge and Planning tools and Financial Tools (united in the same section), and Civic Engagement tools. This approach allows a closer approximation to the current challenges of historic cities. The study of these areas of interest is contrasted with the data derived from the analysis of the Periodic Reports, from which conclusions are obtained on the functioning and adaptation in Spain of these tools to the new holistic approach promoted by UNESCO.

\subsubsection{Regulatory Systems. Protection and Management of Historical Ensembles}

In Spain, the normative frame of reference for Spanish Historical Heritage in the entire territory is Law 16/1985. An advanced law at the time of its approval, it enshrined a broad definition of Historical Heritage and introduced protection figures aligned with the growing recognition of the diversity of values that make it up: "Spanish Heritage is integrated into immovable and movable objects of interest-artistic, historical, paleontological, archaeological, ethnographic, scientific or technical. The documentary and bibliographic heritage, the archaeological sites, as well as the natural sites, gardens and parks, which have artistic, historical or anthropological value, are also part of it" (article 1.2). Recently, Law 10/2015 of May 26 ordered the inclusion of the following final paragraph to said article: "Likewise, the properties that integrate the Intangible Cultural Heritage form part of the Spanish Historical Heritage, in accordance with what is established in its special legislation." Among the preservation legal provisions outlined were the Historical Ensembles, defined as "The groupings of properties that form a continuous or disperse foundation unit, conditioned by a physical structure that is representative of the evolution of a human community as testimony of its culture, or constitutes a use/enjoyment value for the collective" (article 15.3).

In the Spanish case, the division of powers between the State and Autonomous Communities has led to the enactment of regional laws that, based on state law, have been adapting patrimonial protection according to the realities of each territory. A point of interest is that these laws have been sensitive to the new international criteria and recommendations on the matter, as seen in the incorporation of recent patrimonial typologies-industrial heritage, the cultural landscape or intangible heritage have been the subject of special attention, and albeit to a lesser degree, quite linked to the patrimonial reality of the territory and the circumstantial interest. Considering the landscape, the Autonomous Communities (regions) have been responsible for the promulgation of some specific laws on the subject, mainly from the European Landscape Convention (Florence, 2000), as well as the elaboration of detailed catalogs of landscapes of which in many occasions the urban element is an inevitable part. The interest in landscape is not anecdotal in our case, because it is the best example of the change of paradigm operating in recent decades, which has gone from focusing attention on the physical elements of heritage to putting at the center of the question aspects such as the perception or the character of a certain space "Landscape means an area, as perceived by people, whose character is the result of the action and interaction of natural and/or human factors" (art.1 European Landscape Convention [62]). However, there are still important divergences between regions in relation to their integration with the patrimonial legislation, generated to a large extent by the inexistence of an express reference in the Spanish Historical Heritage Law of 1985. This is precisely one of the points that would justify a necessary update of the State Law [63]. 
Finally, the municipal administration has a fundamental role in the management of cities. It has competencies in the field of tourism, active promotion policies, cultural dissemination and cataloging, while the City Councils are also responsible for the design and application of the urban planning instruments-Urban Development Plans and Special Plans for Historic Centers-where applicable.

A system of patrimonial protection has been built over the last forty years on this legal framework that, in general terms, can qualify as successful. Spanish regulations have been able to curb many of the practices that threatened the conservation of their heritage based on traditional principles such as the cataloging of heritage assets, the declaration of properties subject to a special protection regime-Cultural Interest Properties (BIC) - the introduction of control and promotion measures-rights of expropriation or trial and error; fiscal aid for conservation and restoration activities-and the promotion of culture through education. In the case of Historical Ensembles, the legislation establishes two broad competence levels. The regions are responsible for the conservation and enhancement of cultural assets located in their territory and for developing administrative bodies with technicians and public workers, responsible for the control and management of historical heritage. The municipal authorities are responsible for the planning of urban development, as provided by Law $7 / 1985$ regulating the rules of local government (art. 25), and collaborating with state or regional authorities in matters of historical heritage, but without authority in the decision making.

It can be concluded that the Spanish legal framework is identified with what has come to be called the "Conventional approach" to heritage conservation and management. A methodology adopted with the birth of the modern conservation movement in the Western world, with a key reference in the Venice Charter of 1964; where the focus was on the material conservation of the works, identified as monuments and sites to be preserved for the sake of future generations [11]. However, the development of regional laws has allowed the progressive incorporation of new approaches and heritage categories, adjusting the system to the current requirements of Spanish cultural heritage, including the World Heritage cities.

This is confirmed by the SWHC leaders themselves, following the analysis of the Periodic Reports. To the question "Is the legal framework (i.e., legislation and/or regulation) adequate for maintaining the Outstanding Universal Value including conditions of Integrity and/or Authenticity of the property?", 10 of them (71\%) answered that the legal framework is completely adequate for maintaining the OUV (Alcalá de Henares; Aranjuez, Ávila, Cáceres, Cuenca, Ibiza, Salamanca, Santiago de Compesterla, Toledo and Úbeda/Baeza), while, for the remaining four, the problems were focused on its implementation (Granada, Córdoba, La Laguna and Segovia).

\subsubsection{Knowledge, Management and Financial Tools. Planning and Management of SWHC}

A review of the management documents put in place by the SWHC reveal the interest to move towards more and more integrated models, in which the conservation of assets appears linked to strategic plans in the field of tourism, education, financing, residential development and traffic. The following table (Table 4) shows the fundamental data of these plans. Note that many of them have been approved or revised very recently, demonstrating the relevance of the problem. It also includes the existence or nonexistence of specific management organizations that bring together the various administrations involved.

Table 4. Management Plans of the SWHC and Special Management Organizations.

\begin{tabular}{ll}
\hline ALCALÁ DE HENARES & TOLEDO \\
Management Plan: Special Plan for the Protection of the & $\begin{array}{l}\text { Management Plan: Special Plan for Toledo's Historic } \\
\text { Quarter (1997). }\end{array}$ \\
$\begin{array}{l}\text { Historic Center (1997). } \\
\begin{array}{l}\text { Observations: The Plan contemplates the incorporation of } \\
\text { sectorial plans on mobility, tourism or infrastructures. Special } \\
\text { Management Organizations: }\end{array} \\
\begin{array}{l}\text { Consortium constituted by the City Council, the University } \\
\text { and the Autonomous Community of Madrid (2003). }\end{array}\end{array} \quad \begin{array}{l}\text { City of Toledo Consortium (2001), integrated by the } \\
\text { national, regional, and local public administrations. }\end{array}$ \\
\hline
\end{tabular}


Table 4. Cont.

SANTIAGO DE COMPOSTELA
Management Plan: Special Plan for the Protection and
Rehabilitation of the City of Santiago de Compostela (1997).
Observations: In the future, adaptive changes will need to be
foreseen in the Special Plan for the Protection and
Rehabilitation of the City of Santiago de Compostela to
preserve issues like traditional commercial activities, to
support the policies of conservation of buildings and
monuments, as well as the recovery of degraded spaces (WHC-
Retrospective Revision UOV).
Special Management Organizations: Consortium of Santiago
de Compostela (1991), integrated by the national, regional, and
local public administrations, as well as the archbishopric and
the University.

\section{CÓRDOBA}

Management Plan: Special Plan of Historic Ensembles (2001).

Observations: It foresees the integration of other sectorial plans, such as accessibility. Many of these actions will need to be integrated into a World Heritage Management Plan to be drawn up by the Town Council (WHC- Retrospective Revision UOV).

Special Management Organizations: Non-existent.

SAN CRISTOBAL DE LA LAGUNA

Management Plan: The Special Plan for the Protection of the Historic Ensemble (2005).

Observations: non-relevant observations.

Special Management Organizations: Non-existent.

\section{ÚBEDA Y BAEZA}

Management Plan: Management Program of Úbeda and Baeza (2003).

Observations: non-relevant observations.

Special Management Organizations: Úbeda-Baeza World Heritage Consortium (2009), integrated by city councils and universities.

\section{ÁVILA}

Management Plan: Special Management Plan of Ávila, World Heritage City (in process).

Observations: Document in line with the latest theoretical and methodological trends.

Understands heritage as the backbone of sustainability initiatives and policies (territorial, social, economic, touristic, etc.)

Special Management Organizations: Non-existent.

\section{SEGOVIA}

Management Plan: Master Plan of the city (2007). Special Plan of Historic Areas and the Aqueduct's Management Plan (in process).

Observations: The new document is framed in line with the latest theoretical and methodological trends, with special attention to Historic Urban Landscape.

Special Management Organizations: Non-existent.

\section{CÁCERES}

Management Plan: Revitalization and Protection Special Plan of the Archaeological Heritage of the City of Cáceres (1990). Updates from the new General Plan of the Municipality for the town of Cáceres (2010). Observations: The plan will also need to be adapted to meet regulations at the national and international levels and to define a coherent and global project for the city, establishing guidelines and priorities with the objective of a physical and functional rehabilitation of the historic city (WHC-Retrospective Revision UOV).

Special Management Organizations: Consortium of the Monumental City, comprised of the City Council of Cáceres, the Regional Government of Extremadura and Central the Government of Spain (2013).

\section{CUENCA}

Management Plan: Special Scheme for the Planning, Improvement and Protection of Cuenca's Old Quarter and its Valley (2001).

Observations: non-relevant observations.

Special Management Organizations: Real Patronato of the City of Cuenca (2014), integrated by the national, regional, and local public administrations.

\section{IBIZA}

Management Plan: Special Plan for the Protection of the Historic Ensemble (2005).

Observations: non-relevant observations. Special Management Organizations: Non-existent.

\section{GRANADA}

Management Plan: Alhambra Master Plan 2007-2020;

Albaicín Master Plan (in process).

Observations: non-relevant observations.

Special Management Organizations: Due to the characteristics of the property, there are two competent bodies in management: the Patronato de la Alhambra, which manages the Alhambra and Generalife complexes; and the Albaicín Foundation/Agency, an Autonomous Municipal Body.

\section{SALAMANCA}

Management Plan: Management Plan of the Old City of Salamanca (2017) (in process).

Observations: Document in line with the latest theoretical and methodological trends.

Understands heritage as the backbone of sustainability initiatives and policies (territorial, social, economic, touristic, etc.) Special Management Organizations: Non-existent.

\section{ARANJUEZ}

Management Plan: (in process).

Observations: Management of the territory is carried out on various levels by different bodies: National Heritage, Tagus Hydrographic Confederation, Ministerio del Interior (Spain's Home Office), RENFE, Autonomous Community of Madrid, and City Council.

Special Management Organizations: Non-existent.

Source: Own elaboration.

The analysis of these documents, as well as of other measures and ordinances involved in the management of the SWHC - particularly the different Urban Development Plans, and other sectorial plans on mobility, accessibility, tourism, trade, etc.- - show that most of the challenges faced by historic cities are widely known. It far exceeds the objective of this work to deconstruct each of these plans and 
their implemented measures; therefore, Toledo and the valuable programs that it has carried out will serve as the example.

Toledo (Figure 2a) is the perfect example of the overlap of cultures and artistic styles since ancient times. Its walled precinct preserves the imprint of the different populations that have inhabited it (Romans, Visigoths, Jews, Arabs and Christians). Its political, social and economic weight was of the first order since the middle ages; and its image has been continually evoked and recreated, especially by romantic travelers of the nineteenth century. Although many of its buildings have been declared National Monuments since the mid-nineteenth century, in terms of protecting the historic city, Toledo is, together with Santiago de Compostela, the first historic complex declared a Historic-Artistic Monument [64]; a fact that undoubtedly contributed to the preservation of its values in the face of the constructive excesses that characterized the decades of the 1950s to the 1970s in Spain.

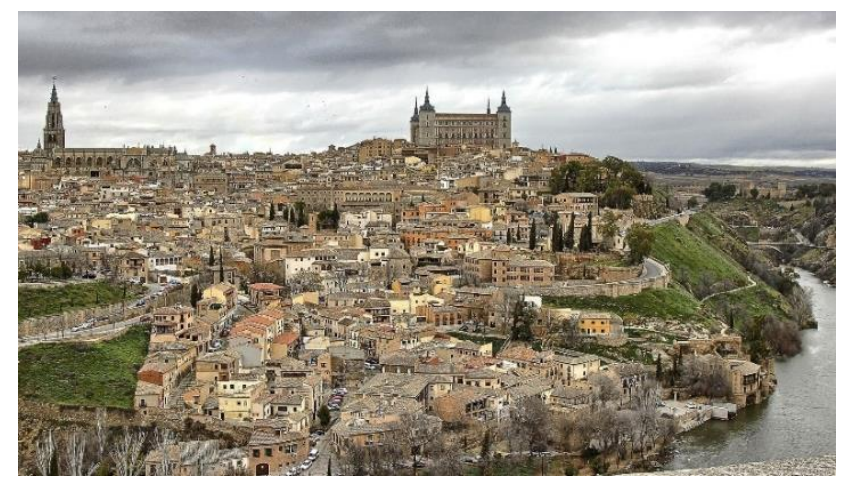

(a)

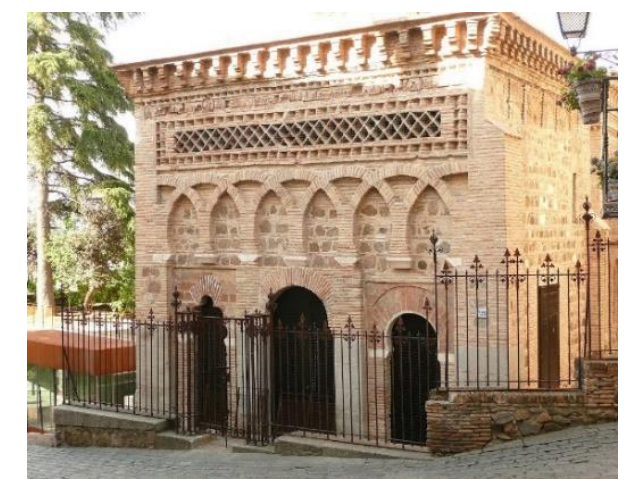

(b)

Figure 2. (a) View of Toledo from the Tajo River Valley; and (b) Former Mosque of Bab al Mardum (10th century), converted into a hermitage in the 12th century, popularly known as "del Cristo de la Luz."

After its designation as a World Heritage Site in 1986, a Special Plan for Toledo's Historic Quarter was approved and launched in 1997. In addition, two municipal ordinances were approved: The Ordinance of the Spatial Plan of the Historic District of Toledo, PECHT (1998) and the Municipal Ordinance Regulating the Aid for the Rehabilitation of Buildings and Homes in Execution of the PECHT (2001). The Plan would define a future city model and reverse the process of deterioration and depopulation that the historic center had been suffering since the beginning of the 1980s. To that end, it focused on the provision of infrastructure and residential improvement, with an ambitious proposal of housing recovery. The challenge, as it continues to be today, was reconciling and balancing the various areas of urban consumption-tourism, commercial, institutional and residential—addressing issues such as the circulation of vehicles in the historic area, through the construction of parking areas at the entrance of the historic center and escalators that bring the pedestrians closer to the center.

To facilitate the implementation of the Plan, in 1998 the Royal Board of the City of Toledo was created (Decree 1424/1998 of July 3), formed by the different administrations involved-state, regional and local - to promote and coordinate conservation actions and the revitalization and enhancement of the historic city. In 2001, the Consortium of the City of Toledo was set up as a management entity of the Board of Trustees, which has since done very important work through various action programs: Infrastructure and Rehabilitation, Public Heritage and Facilities, Monumental Heritage, Archaeological Heritage and Cultural Dissemination. The results of the Toledo Consortium's activities, which can be found on-line, perfectly illustrate their role in the revitalization and rehabilitation of the historic center of Toledo. In the field of housing, the Consortium advises and manages grants that can reach up to $65 \%$ of the total budget of the rehabilitation work. In 2016, the Consortium granted 152 rehabilitation aids for a total amount of 1,084,000 $€$ [65]. Its technicians conduct nearly 800 hearings per year and as of 2016 a total of 3350 rehabilitation interventions were carried out-270 annual 
interventions until 2012, at which time the effects of the economic crisis began to be evident. In addition, the rehabilitation of commercial premises located in the area affected by the Plan has been subsidized since 2007. On a separate note, the Consortium has carried out all kinds of actions to improve the public space-from the widening of streets to the redevelopment of squares, façade arrangements or elimination of wiring - and, through the programs of Monumental Heritage and Archaeological Heritage, the recovery and enhancement of innumerable assets (convents, towers, churches, etc.). Some of these are new and important heritage attractions that diversify and strengthen the cultural value-Cuevas de Hércules, Roman baths, Mosque of El Salvador, Mosque of Cristo de la Luz, etc. (Figure 2b). Routes of unknown heritage, driven by the Consortium, attracted more than 180,000 visitors from 2011 to 2016 [65]. Connected to all this activity, an interesting initiative started in 2011 that is linked with the economic sustainability of the territory, was the launch of a standardization for companies and craftsmen who work in rehabilitation with traditional techniques.

However, the case of Toledo is not unique. In almost all SWHC, to a greater or lesser extent, initiatives of this type can be found. In Segovia, for example, the establishment of the Rehabilitation Area of the Historical Center of the Jewish Quarter and its Technical Office in 2005, made it possible to reconcile the granting of aid for rehabilitation with the recovery of the historical Jewish quarter, taking into account both its historical-artistic characteristics and the social and economic rehabilitation of the area. In Santiago de Compostela, the activities developed since the establishment of the Consortium of Santiago (1992) are also numerous and notable in all the areas indicated. One of its most innovative initiatives has been the creation, in collaboration with the National Geographic Institute, of an online Heritage Information System that includes all types of data related to immovable heritage: written or graphic historical and archaeological documentation, inventory of cultural elements inside of monuments, archaeological surveys, cadastral information, historical plans, evolution of the urban fabric, etc. [66] (Figure 3).

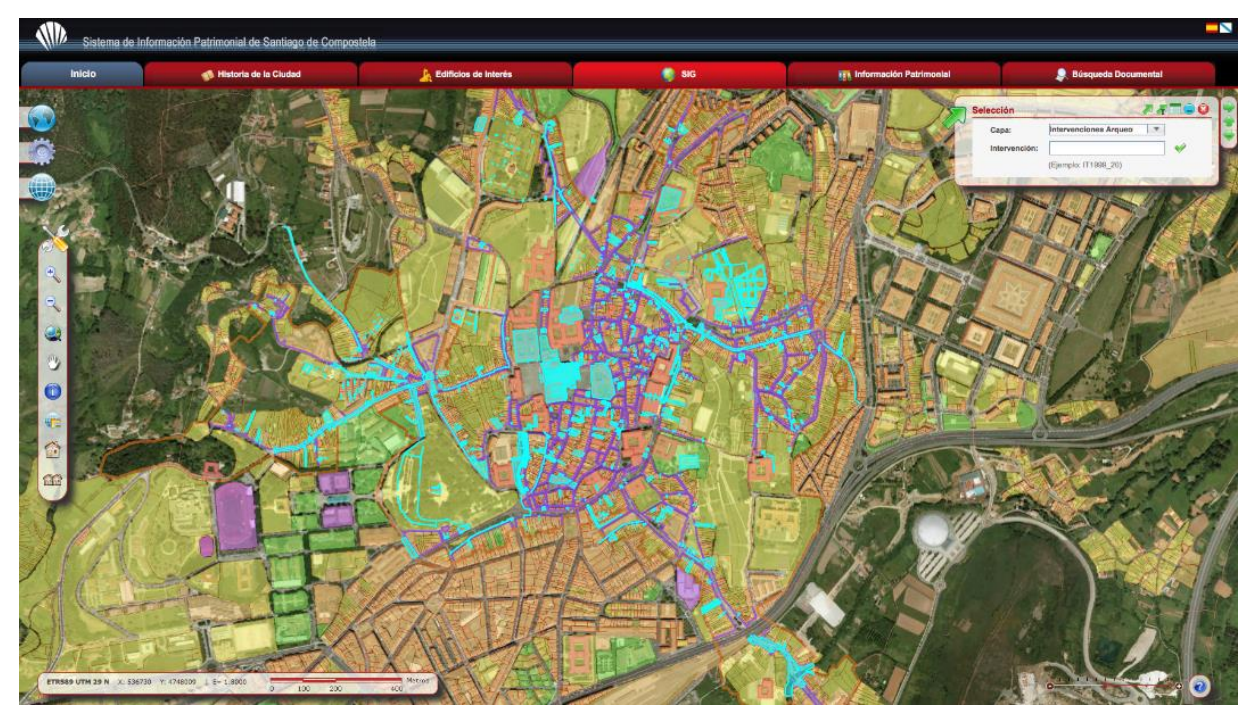

Figure 3. Heritage Information System. Consortium of Santiago and the National Geographic Institute.

Comparing the above with the different Periodic Reports, the question "Is the management system or plan adequate to maintain the property's Outstanding Universal Value?" shows that seven of the SWHC (50\%) considered them perfectly adequate (Aranjuez, Ávila, Córdoba, Salamanca, Santiago de Compostela, Toledo, and Úbeda/Baeza); five SWHC (36\%) considered them only partially adequate (Alcalá de Henares, Granada, Cuenca and La Laguna); and two of them (14\%) (Cáceres and Segovia) declared that they did not have a corresponding Management Plan at the time. With these answers, we must point out the apparent contradiction that cities without a Management Plan updated at that 
time consider the management system appropriate, which in many cases is explained by the previous existence of partial tools, legislations and administrations, an example being Aranjuez.

Regarding the financing, it is asked: "Is the current budget sufficient to manage the World Heritage property effectively?" In response, three SWHC (Aranjuez, Toledo, and Úbeda/Baeza) considered "The available budget is sufficient but further funding would enable more effective management to international best practice standard" (21.5\%); eight SWHC (57\%) said "The available budget is acceptable but could be further improved to fully meet the management needs" (Alcalá de Henares, Granada, Ávila, Córdoba, Cuenca, Ibiza, Salamanca and Santiago de Compostela); and only three SWHC (21.5\%) (Cáceres, La Laguna and Segovia) declared that "the available budget is inadequate for basic management needs".

\subsubsection{Civic Engagement Tools}

"Community involvement in urban heritage is about involving [...] people, institutions and organizations, that are interested in the urban heritage, affected by the urban heritage or live within or close by the urban heritage, in the preservation, management and promotion of the urban heritage and its beneficial use for the local communities [67] (p. 15)." The Guidebook on Community Involvement in Urban Heritage [67], recently published by Organization of World Heritage Cities (OWHC), in cooperation with the European Union, Council of Europe and Eurocities, points out the existence of three community profiles linked to heritage: People that are "interested" belong to the so-called "Heritage Community" - "also residents, users, owners, tourists, etc. can be part of the 'heritage community' if they positively identify with the urban heritage and want to act as supporters [67] (p. 15)." The "affected" community can be understood as residents, tourists, and/or people who are connected to the urban heritage through their daily life or work. In the end, people that "live within or close by" the urban heritage are residents that may or may not feel a connection to it nor affected by it; but the key is to investigate how these residents feel about the heritage, what they understand about it and their relationship to the area in which they reside [67] (p. 15).

From the point of view of sustainability, systems and models of participation in decision-making are frequently studied in the tourism literature-Tosun and Timothy [68]; Zhang, Cole and Chancellor [69]; and Jordan, Vogt, Kruger and Grewe [70]. However, it has also gained relevance in recent years in relation to the management of World Heritage sites and assets, as we see in Brown and Hay-Edie [71] or Li and Hunter [72]. In this line, the landscape concept allows the adaptation of models such as the participatory construction of cultural maps, as Taylor and Cook, I. [73] demonstrates.

Distinct theoretical models and scales of participation are gathered in the pages of The Guidebook on Community Involvement in Urban Heritage ranging from the most passive to the most active, a ladder whose steps are based on education and promotion policies and lead to states where citizenship is gradually gaining prominence in decision-making. First, through information and consultation procedures, the population is acquiring a more active role, functioning in many cases as guardians of compliance with regulations. As the citizenship establishes its role and it gains power, it enters a stage of true collaboration with the administration managers at the time of designing and influencing the management process. Finally, in the last steps, there are models in which the highest degree of decision and management capacity is transferred to citizenship; a kind of self-management that leaves the public administration as support and guarantor of the achievement of the measures adopted [67] (pp. 17-19). These last degrees of self-management, the identification, conservation and management of cultural heritage by the public, are also indicated by the "Living Heritage" model promoted by ICCROM, which seeks to put the living dimension of heritage at the core of decision-making, thus the importance of empowering communities in the conservation and managing process [18-20].

In Spain, the process used to create Management Plans, as far as citizen participation is concerned, takes quite a traditional approach. The technical specialists create the plan and the public is informed through various processes. The plan is debated with stakeholders such as the Royal Academies of Fine Arts or History, Associations for the protection of heritage, neighborhood associations, round tables, 
conferences, etc. Then, propositions are extracted that can partially modify the primitive document. In any case, this is a participation conditioned by a previous document, designed with a top to bottom approach. It is worth asking if this is really participation; if so, what is the model and the degree of participation that is pursued in the management of the SWHC? Is the necessity of community involvement being emphasized and the People-Centered approach to conservation being promoted? However, above all, it must be asked if the current participation model provides the degree of recognition and desirable citizen implication for the sustainability of the SWHC. Once again, the joint analysis of Periodic Reports allows us to assess the degree of adaptation to the new paradigm in questions of citizen participation, taking as reference some questions from the questionnaire.

The following image shows the results from the observation "Please rate the awareness and understanding of the existence and justification for inscription of the World Heritage property among the following groups" (Figure 4). An important difference is observed between recognition and appreciation by the authorities, excellent or average, and other groups such as local communities, visitors or landowners, where the value "poor" is much more frequent. In the same way, the results of the "businesses and industry" sectors are worrisome - even those referring to the tourism industry are "poor" in at least three SWHC (21.5\%) (Aranjuez, Ibiza and Ubeda/Baeza).

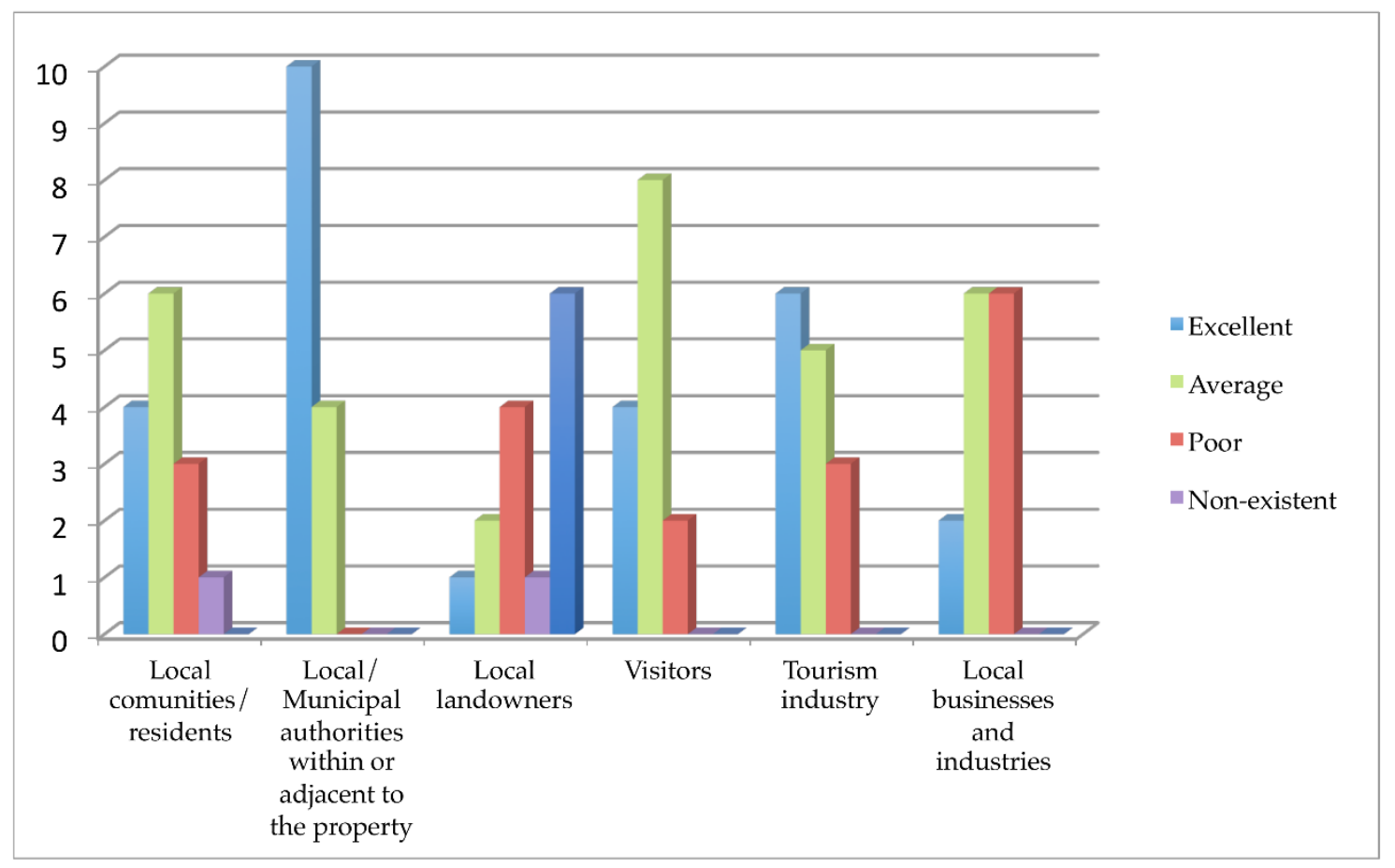

Figure 4. Awareness and understanding of the existence and justification for inscription of the World Heritage property amongst the following groups. Own elaboration based on the findings in the Periodic Reports.

A good example of the disconnection between the protection and management measures adopted and the citizenship is found in the understanding of boundary zones and buffer zones. About the question "Are the boundaries of the World Heritage property known?", only in eight of the 14 SWHC $(57 \%)$ answered that "The boundaries of the World Heritage property are known by both the management authority and local residents/communities/landowners". For the rest of the cities $(43 \%)$, "The boundaries of the World Heritage property are known by the management authority but are not known by local residents/communities/landowners" (Aranjuez, Ávila, Cáceres, Salamanca, Segovia and Ubeda/Baeza). 
This percentage decreases considerably in the case of buffer zones. To the question "Are the buffer zones of the World Heritage property known?", only three of the 10 SWHC (21.5\%) (Ibiza, Salamanca and Santiago de Compostela) showed that "The buffer zones of the World Heritage property are known by both the management authority and local residents/communities/landowners." The other seven SWHC (50\%) indicated that "The buffer zones of the World Heritage property are known by the management authority but are not known by local residents/communities/landowners", and four SWHC (28.5\%) indicated that at that time the city did not have a buffer zone (Ávila, Cáceres, Córdoba, and Segovia). As Lalana Soto pointed out, a Buffer Zone is a tool that not only helps preserve the heritage values of the declared areas, but also works as a hinge, as areas of cooperation that connect the heritage with the people who inhabit it. Therefore, its character should not be merely restrictive, but should seek to reconcile with the development and sustainability interests of local communities, respecting the sense of place (genius loci) [74] (pp. 8-9); for this, the knowledge and implication of the citizens in its regulation is fundamental.

To mitigate this problem, the designation of World Heritage must be accompanied by an adequate policy of education, information and awareness-building activities. In the case of SWHC, the inequality regarding the implementation and development of "education and awareness programs" is striking. To the question "Is there a planned education and awareness program linked to the values and management of the World Heritage property?", five SWHC (36\%) answered "There is a planned and effective education and awareness program that contributes to the protection of the World Heritage property" (Granada, Ávila, Ibiza, Salamanca and Santiago de Compostela); three SWHC (21.5\%) andswered "There is a planned education and awareness programme but it only partly meets the needs and could be improved"(Aranjuez, La Laguna and Toledo); two SWHC (14\%), "There is a limited and ad hoc education and awareness programme" (Alcalá de Henares and Córdoba); and four (28.5\%), "There is no education and awareness programme, despite an identified need" (Cuenca, Cáceres, Segovia and Ubeda/Baeza).

However, it is in those issues related to the involvement of citizens and different stakeholders in decision-making, management and monitoring of cultural assets, where SWHC present poorer results. To the question about the "Cooperation and input of local communities in management decisions", only two of the 14 cities (14\%) (Salamanca and Santiago de Compostela), expressed that "Local communities directly contribute to some decisions concerning management." Of the rest, $11(80 \%)$ are limited to recognizing "some input, but no direct role in management" - an answer that must also be put in context, because in too many cases the participation is limited to information sessions in which the participating groups, representatives of the associative fabric of the city, work on documents that are practically sealed, hardly permeable to any major changes. Cáceres $(7 \%)$ responds that "Local communities have no input into decisions relating to the management".

More illustrative are the answers about the "Cooperation with industry regarding management" and the cooperation with the tourism industry to improve the visitor experience and the conservation of the values of the World Heritage property. In the first case, up to nine of the 14 SWHC (64.5\%) declare to maintain "little or no contact with industry regarding the management of the World Heritage property buffer zone and/or area surrounding"; Segovia declared that "There is contact but little or no cooperation with industry" (7\%); Granada, Salamanca and Ubeda/Baeza answered that "There is contact but only some cooperation with industry" (21.5\%); and only Aranjuez states "There is regular contact with industry" (7\%). In the second case, there are also nine (64.5\%) cities that in response to the question "Does the tourism industry contribute to improving visitor experiences and maintaining the values of the World Heritage property?" said "There is limited co-operation between those responsible for the World Heritage property and the tourism industry to present the Outstanding Universal Value and increase appreciation"; three SWHC (21.5\%) (Ávila, Cáceres and Úbeda/Baeza) said that "there is contact between those responsible for the World Heritage property and the tourism industry but this is largely confined to administrative or regulatory matters"; one only two SWHC (14\%) (Salamanca and Santiago de Compostela) indicated that "there is excellent co-operation". 
All the previous answers are in line with what the graphic referred to as "the level of involvement in monitoring of the different groups" (Figure 5), where it can be seen as an important contrast between the good results obtained by managers and authorities, and those that refer to the participation of local communities and other stakeholders, much poorer. This points to what is probably the biggest challenge facing the SWHC in adapting to the new international paradigm: only from the progressive and effective participation of the community and the different stakeholders in decision-making will it be possible to move towards the conservation, sustainability and economic objectives of our cities. The last graph is eloquent in this sense, since it should be generalized, and not exceptional $(21.5 \%)$, that in the cities there is a "major flow of economic benefits to local communities from activities in and around the World Heritage property" (Figure 6).

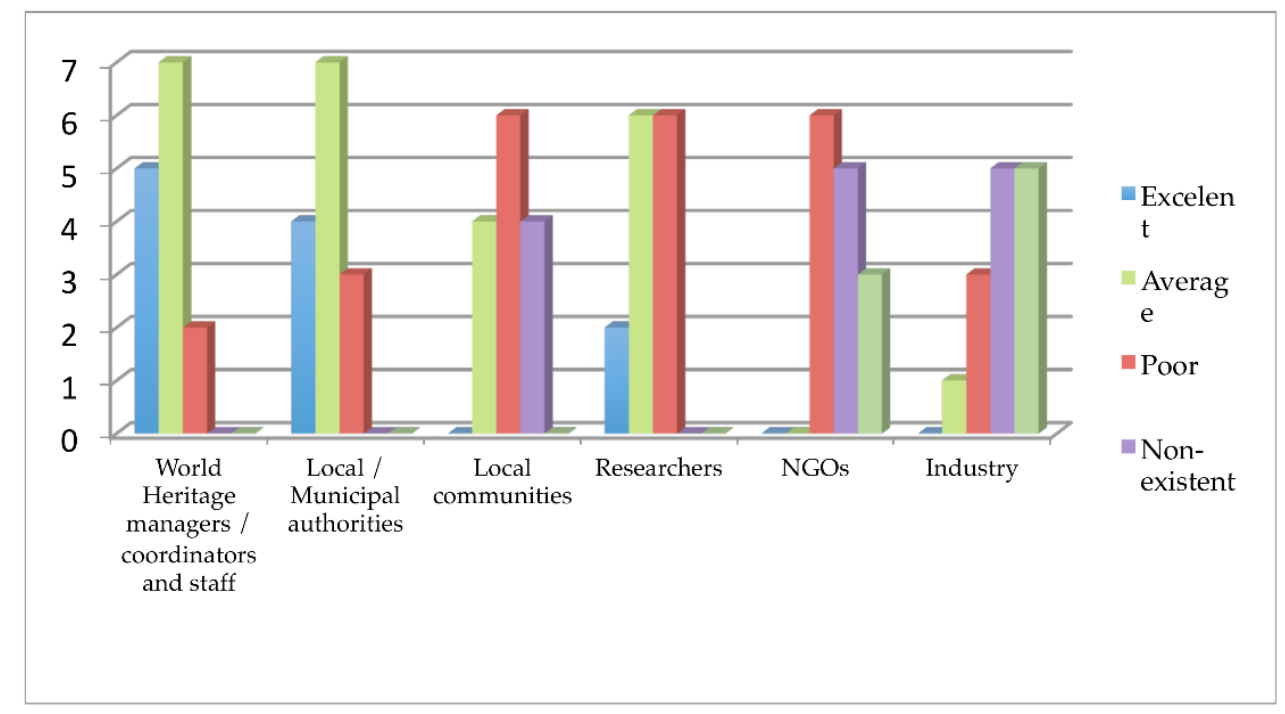

Figure 5. Level of involvement in monitoring the World Heritage property. Own elaboration based on the findings in the Periodic Reports.

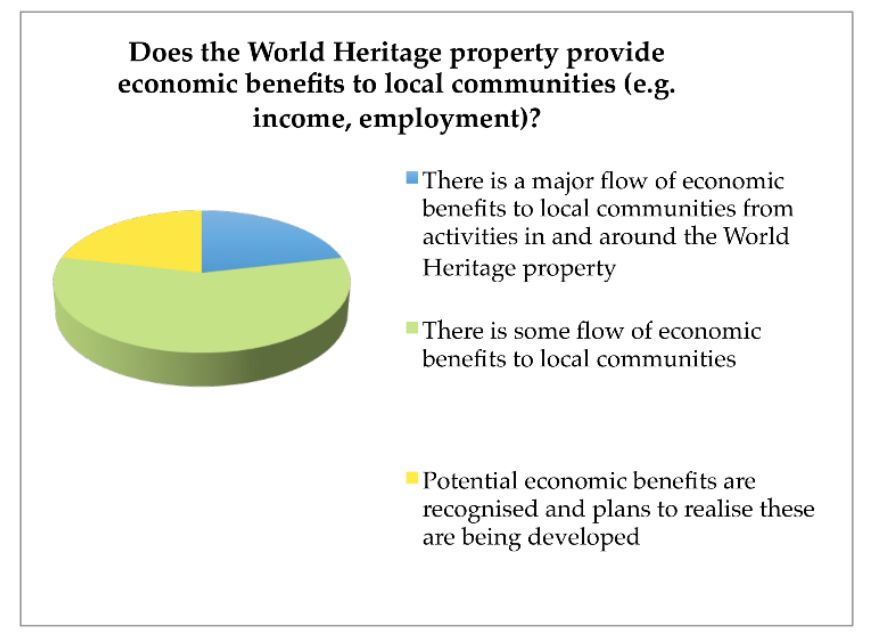

- Granada, Salamanca,

Toledo.

- Alcalá de Henares,

Cáceres, Córdoba,

Cuanca, La Laguna,

Segovia,

Úbeda/Baeza.

Aranjuez, Ibiza,

Santiago de

Figure 6. Economic benefits provided by the World Heritage property to local communities. Own elaboration based on the findings in the Periodic Reports.

In conclusion, in SWHC, it is still evident that participatory processes are mostly reduced to the so-called "heritage community" and that, in any case, the role and decision-making capacity of this community is still far from the highest levels of citizen empowerment. The greatest challenge is 
probably to make citizen participation a much less passive and limited activity than has been the case so far. It is worth pointing out, that in Spain there is a weak tradition on the subject, as evidenced by the data previously analyzed. Considering the aforementioned scale, it can be concluded that presently the SWHC are moving along the first rungs of the ladder and education and awareness policies are still very necessary. However, it is also important to note that in successful states participatory activities may end up being just a form of tokenism, if there is no real willingness to yield the responsibilities of decision-making to the public [67] (p. 18).

\section{Implementation of the New Holistic Paradigm in SWHC}

In Spain, the assumption of the new holistic paradigm as a SWHC management model has been slow and has followed a path not without difficulties. In fact, it can be said that its implementation is still precarious.

Concentrating on the historic urban landscape, its impact on the scientific literature continues to be scarce in comparison with the enormous impact that the European Landscape Convention had in the year 2000. It is also symptomatic that the National Cultural Landscape Plan, a document in continuous development since 2002, does not refer specifically to the HUL Recommendation and its integration into landscape policies [75]. The doubts about its need and its conceptual and practical implications have been extensive among the sectors involved since the Memorandum of Vienna in 2005. Thus, Lalana Soto pointed out the difficulty of applying the concept of historic urban landscape in practice [76] while Azkarate and Azpeitia put forward the risks derived from approaches "undoubtedly well-intentioned, but excessively ambiguous in their generic formulations and, consequently, with too many open flanks where real estate interests attack with impunity" [77]. The danger is that, under such a generalist approach, the procedures for managing change in cities are not adequately developed, which would lead to a deregulation of protection and conservation criteria with unforeseeable consequences.

In September 2007, the Joint Report made by members of ICOMOS, ICCROM and UNESCO-WHC, after the "Seminar on Control and Management of Urban Planning in Spanish World Heritage Cities" held in Aranjuez, discussed the application of the Memorandum to Spanish cities' world heritage, with the following diagnosis [78]: The concept was problematic and caused misunderstandings, some participants felt that the intent was to replace the concept of "historic center" with "historic urban landscape", causing alarm. In Spain, there were two main contrasting groups, the urban planning authorities and the conservationists-represented by ICOMOS Spain and other NGOs. Architects seemed to be the most influential group responsible for urban planning in the local authorities. The Vienna Memorandum had been interpreted and applied to justify large-scale contemporary development projects within the historic context, causing the particularly critical viewpoint of the conservationists.

Linked to its status as a Cultural Landscape, in 2007 the Alhambra of Granada became the first cultural asset to have a Management Plan that integrated the protection of the monument with its territorial implications, paying attention to the balance between its conservation, use and enhancement to guarantee the maintenance and growth of its monumental, cultural and symbolic values [79]. One of its greatest challenges was, precisely, the sustainability of the tourist activity and the management of the flow of visitors. In 2016 the Alhambra welcomed 2.61 million tourists, surpassing records from 2015 by $5.7 \%$ and surpassing its number of visitors for the fourth consecutive year; the 2016 figure represents $95 \%$ of its maximum capacity for conservation reasons, established at 2,763,500 per year [80]. However, this plan fundamentally affects the space and immediate surroundings of the monument, with little urban incidence. Not until 2013, the neighborhood called Albaicín, an integral part of the area declared a World Heritage Site by UNESCO, granted the first Landscape Plan, implemented by the Albaicín Agency-an autonomous municipal organization in charge of its management. It must be noted, however, that both this Landscape Plan, and other similar initiatives promoted by the Albaicin Agency-Local Operational Program (2002), URBAN Community Initiative Program (2002-2007), and Tourism Program—follow a traditional strategy of actions aimed at the recovery or preservation 
of the visual values of the space, as well as other classic initiatives of restoration, information and communication of the cultural values of the Albaicín [81]. Only recently, the Agencia Albaicín has begun to work on a true Management Plan of the Albaicin World Heritage, presenting in 2016 the first technical draft from which to establish a true program that, now, must include as an ineludible axis the issue of citizen participation for sustainable management [81]. In this line, initiatives such as the recent creation of a Citizen Participation Space for the improvement and management of the Albaicín and Sacromonte neighborhoods begin to emerge [82].

Despite the slowness and some reticence already mentioned, the new holistic paradigm continues to gain ground when it comes to conceiving the management policies of the SWHC. In 2015, the Group of World Heritage Cities of Spain, an association created in 1993 that brings together several Spanish SWHC, commissioned and published a White Paper on Management of Historical-Archaeological Heritage whose great interest lies in the revision, reorientation and approach of new management procedures based on the new holistic paradigm and the objective of sustainability applied to historic cities [83]. The document, which aims to be a diagnosis and guide for SWHC, addresses concepts such as the heritage value chain, based on the balance and relationship between the different processes involved in heritage management: research, protection, conservation, interpretation, socialization and evaluation of patrimonial impact. This philosophy seeks to contribute to improving the quality of life of citizens, for which citizen participation is fundamental. The White Paper collects and adopts the concept of historic urban landscape as a tool for the management of complex and dynamic cultural heritage, such as cities, which requires addressing both the geographical aspects that characterize the territory and the diversity of urban, historical, social, material and immaterial elements that determine the way we perceive them and that shape their essence or character. Regarding its sustainability, it is stated: "we must assume that in the historical city the historical process is still ongoing. History has not ended and the historical city must continue its process or, on the contrary, it will cease to be sustainable and will die" [83] (p. 30); for this reason, we must face complications such as: "the ignorance of the urban heritage by its own inhabitants; the difficulty on the part of the managers of avoiding the deterioration and the abandonment of the urban heritage; the often static view of the concept of cultural heritage; the functional modifications of the urban landscape; the economic exploitation of heritage; the massive influx of tourism; mobility and movement flows [83] (p. 31)."

In addition to Granada, the Castilian cities of Ávila, Salamanca and Segovia have been the first to structure their respective management plans by firmly embracing the new holistic paradigm-documents that are in fact in the process of final approval.

In the case of Ávila, the objective of sustainable growth is based on the recognition of the potential of culture and heritage, and the design of a comprehensive and integrated management model. One of the keys of the plan is the concept of an "urban patrimonial system", in which the individual elements yield part of their importance to the recognition of the relationships that are established between them; a system that allows for understanding the city as a set of meanings and ideas, represented and related to each other through material and immaterial elements [56]. The new plan is structured around four strategic axes that aim to address all the factors that influence the city: culture and heritage; territory and heritage; society and heritage; and economy, tourism and heritage. In the area of society and heritage, actions are contemplated in five areas: involvement of young people in knowledge, protection and dissemination of heritage (Patrimonitos-UNESCO Program); urban development and social transformation to provide the historical city with functions within the general urban structure; increase in the involvement and participation of society in the conservation of the city and in decision-making; education and training of citizens; and improvement of social cohesion and development, providing better services to the historic center. For the rest, the promotion of participation focuses on the incorporation of new agents, both in the discussion phases and in the implementation of lines of action, with the Local Council for Sustainability [56]. In other areas, such as the economy, the plan assumes the need to develop specific indicators on trade, development and heritage, as well as on the trade and resident population relationship (Figure 7). 


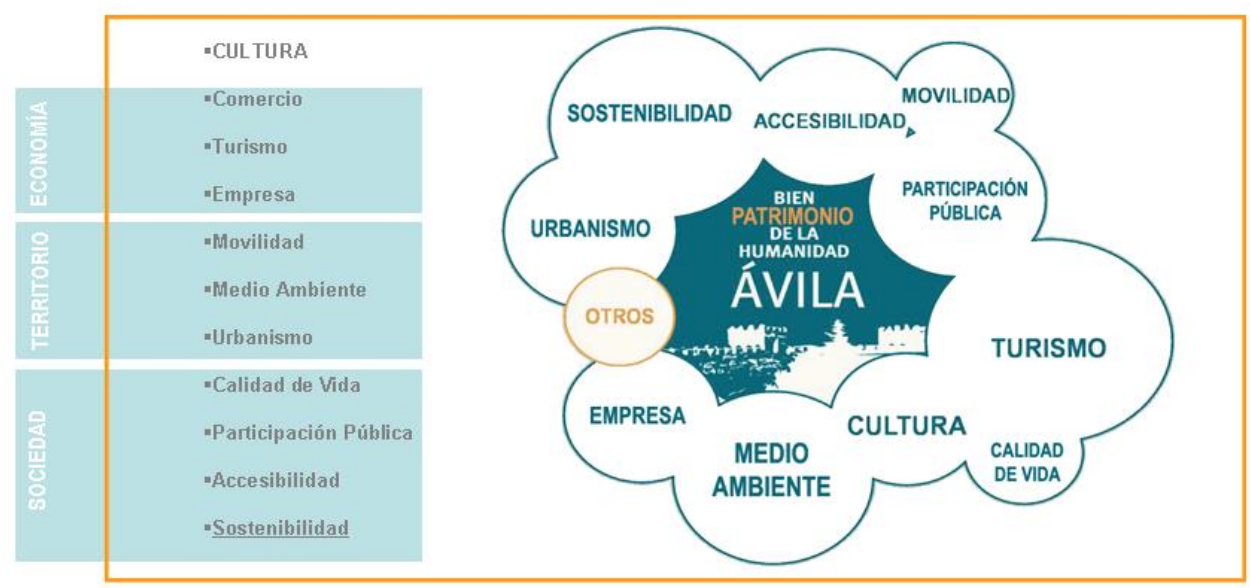

Figure 7. Structure and strategic development of the Special Management Plan of Ávila [56].

The Management Plan of the Old City of Salamanca is on a very similar line [84]. On the one hand, it is an instrument that allows the evaluation and reconsideration of strategies and measures for the protection of urban and architectural heritage; on the other hand, it is an opportunity to introduce an integral vision of the historic city based on the concept of landscape, which has become a tool for controlling the conservation of property. The plan intends to provide an opportunity to rethink the historical space and present the future of the city as a cultural interaction of the tangible with the intangible. The OUV of Salamanca is identified with the following concepts, tangible and intangible, on which the Management Plan is structured: monumental density, cultural identity, vitality/urban livability, environmental and landscape quality and citizenship-which encompasses the feeling of belonging and citizen participation in the management and decision making.

In Salamanca, the historical territorial reading has allowed the identification of structures of urban landscape of high cultural value and identity, as well as points, routes and viewpoints susceptible of protection. Six significant urban environments have been identified, within the framework of the protection, regulation and control of the interior landscape (Libreros, Rúa Mayor and Compañía, Plaza Mayor and Entorno, Cathedrals and San Esteban-Calatrava). Five homogeneous areas of the traditional urban fabric have been targeted, as well as a series of critical areas that constitute opportunities for intervention (Figure 8). Finally, the environments of the Cultural Interest Assets (BIC) have been delimited and the existing catalogs have been updated [85] (pp. 15-20).

From the point of view of the management and monitoring, the plan foresees the creation of a specific Management Office, in which the various administrations participate and involve the interested stakeholders. Likewise, it expresses the concern to ensure mechanisms of effective citizen participation that favor the feeling of belonging and social cohesion, although its development is very scarce, constituting more a series of intentions than a true plan. On the other hand, it recommends the creation of a permanent Observatory that monitors a whole series of indicators to be implemented. Among them, the evolution of the population in the Historic Center, its aging and permanence, the type of employment and trade or hotel weight [85] (p. 24).

In the near future, the approval of the Special Plan of Historic Areas of Segovia is expected [86]. As with the previously mentioned plans, it pursues the integral and sustainable management of the historic city. To this end, it makes use of both tools related to the protection of historical heritage-including the Heritage Catalog and Impact Assessments on Historical Heritage-as well as instruments for urban planning and governance of the territory. Once again, it is the adoption of a landscape approach that allows integrating conservation, management and management policies into one document, and advancing strategies to face the challenges of the historic city of our time. However, scarce references to the construction of a model of city participation that is focused on the construction of a future model of city management from the bottom up are found in the current draft. 


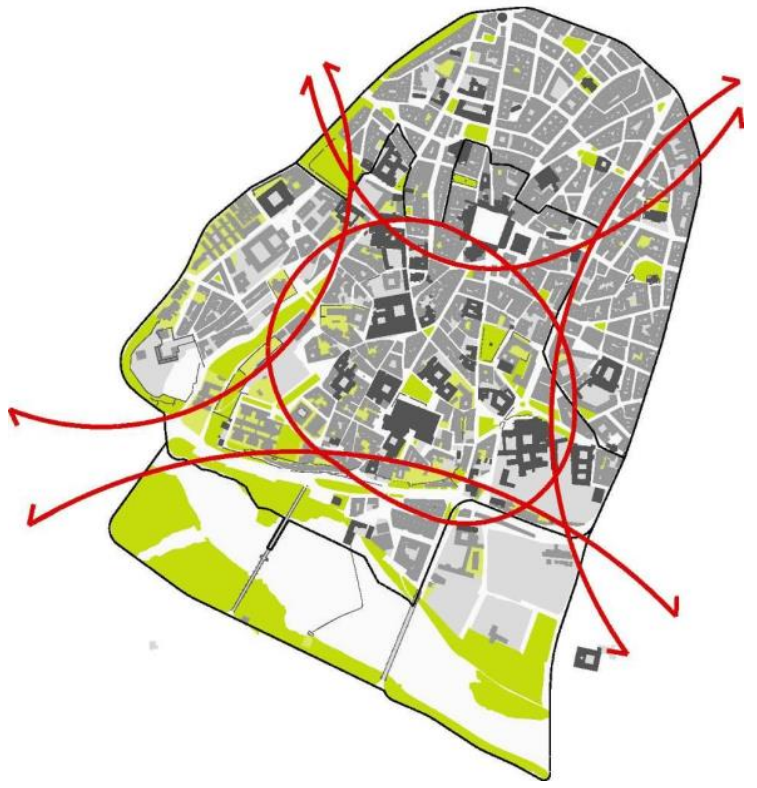

Figure 8. Management plan of Salamanca "homogeneous areas of urban fabric".

Despite the importance of all these plans, inspired by the principles of the new holistic paradigm, in Spain it will still take some time until there are data and proven results on its application, being quantitative and qualitative elements that would allow us to measure the recovery of the historical link between culture, development and sustainability, and the capacity of culture to improve the quality of life of the people.

\section{Conclusions}

The objective of this article was to compare the correlation between the new holistic paradigm and the current reality of Spanish historic cities, for which the SWHC were used as examples.

In relation to the challenges that the SWHC face in terms of sustainability and livability (referring to the first methodological step and Section 4.1), the application of the indicators on population and tourism allowed for interesting conclusions to be drawn:

- First, the SWHC still have a long way to go in the field of sustainability monitoring. In the case studied here, the fact that no SWHC had a population record limited to the area declared a World Heritage Site, as well as inequality when collecting population data from historic centers, reflects poorly. Studies on sustainability indicators are essential and should be promoted, together with their application in SWHC.

- The indicators used in this work have proved valid to register the quality of life of a city and detect ruptures in the city-citizenship-heritage balance. The analysis reveals varied examples of depopulation of historical centers and, above all, a progressive loss of representation with respect to other areas of the city. On the contrary, the continued growth of tourism draws a situation in which the risk of saturation is evident, which can be manifested in phenomena such as museumification, tertiarization and loss of authenticity of the historic city.

- Despite the difficulty in quantifying the limits on load capacity in historic cities [39] (pp. 82-83), the population-tourism trend recorded so far is clear and points to a growing imbalance. It is necessary to strengthen the implementation and evaluation of associated indicators, such as the type of trade and its development in historical areas.

Faced with these phenomena, it was appropriate to assess the management model in the SWHC and their adaptation to the new holistic paradigm promoted by UNESCO (referring to the second 
methodological step and Section 4.2). To this end, the four fundamental tools indicated in the Recommendation on Historic Urban Landscape have been addressed, using for their evaluation the results of the Periodic Reports compiled by UNESCO-WHC. From this portion of the study it is concluded that:

- In Spain, the legal framework and the current projection system is characterized by the division of power among various administrations-national, regional and local. In the case of the SWHC, the regional and local administration are those involved in the protection of their heritage elements and their urban planning. From the point of view of the theoretical model, the Spanish legislation falls within what has come to be called the "Conventional Approach" to heritage conservation and management. In the case of the SWHC, this model creates a separation between the protected spaces and the rest of the city; in the same way, it is fundamentally focused on the protection of the physical elements of the heritage. Actually, even if $71 \%$ of SWHC consider that the legal framework is completely adequate for maintaining the OUV, looking at the holistic paradigm, it obviously requires revision to pay greater attention to intangible elements and, above all, address the interrelation between material and immaterial aspects and the concepts of sustainability and continuity.

- In relation to the planning, management and financing of the SWHC, most of the Spanish cities approved management plans between the end of the 1990s and the beginning of this century. Many of these documents were already trying to address aspects that go beyond mere conservation, supplementing with sectorial plans for tourism, mobility or education; therefore, some of the problems that affect historic cities have been known for some time. Together with the management plans, the increased use of joint management tools between administrations through the creation of consortiums can be qualified as a success-at the moment, $50 \%$ of the cities employ this kind of tool. As the case of Toledo shows, these have had a great impact in terms of conservation, restoration, rehabilitation and enhancement of historical-artistic heritage. Thus, even if there are cases in which there is not yet an implemented management plan $(43 \%$ of SWHC), or in which it is not totally adequate to the needs of the historic city, an evaluation of the last decades should conclude that the SWHC have had adequate financing and planning, consistent with the traditional protection and management model prevailing until recently in the international arena-for $78.5 \%$ of SWHC the budget was sufficient or acceptable.

With regard to the adequacy of this model to the new holistic paradigm, we observe that there is still a lot to be done. Beyond the examples given in Granada, Salamanca, Segovia or Ávila, which come closer through the Historical Urban Landscape, the rest of the SWHC would have to review their management plans to adapt them to the new UNESCO doctrine.

- The management model of the SWHC presents interesting contradictions when confronted with UNESCO's Periodic Reports. These point to a problem that, far from being related to traditional issues-such as the scarcity of financing or the existence and adaptation of protection or conservation measures-has to do with the connection between cultural heritage and citizenship. Thus, poor results are found in issues such as the degree of recognition by the citizenry of the cultural values of the historic city, or their participation in decision-making (Figures 4 and 5). The same is true of collaboration with different stakeholders, such as businesses, including the tourism industry (for $64.5 \%$ of SWHC there is little or no-contact and limited cooperation). When evaluating the flow of economic benefits to the resident population derived from the status of cities as World Heritage, results are also poor (Figure 6).

To conclude, it should be stressed that the issue of participation and community engagement constitutes, without a doubt, the greatest challenge facing the SWHC in the face of the true implementation of the new holistic paradigm. This is a very important challenge, which is probably not being given the attention it requires, not even in the most modern management plans that are currently 
being approved. It seems, in fact, that their inclusion in these documents would be considered as a mere requirement, without actually making the effort that it really requires to define and build a model and degree of desired citizen participation in the management of SWHC. In this regard, there is a line of research that is important to address in future work.

Funding: Department of Art History of the Universidad Nacional de Educación a Distancia, UNED.

Acknowledgments: This work was done during a research stay in the Library of the International Centre for the Study of the Preservation and Restoration of Cultural Property, ICCROM Rome (September-December 2017). I thank its members for all the help and collaboration they provided. This research stay was possible because of the economic help of the department of Art History of the Universidad Nacional de Educación a Distancia, UNED. I would like to thank the municipalities of the different Spanish World Heritage Cities for their collaboration with this study and the provision of data on management, population and trade.

Conflicts of Interest: The author declares no conflict of interest.

\section{References}

1. Troitiño Vinuesa, M.A. Ciudades históricas y dinámicas urbanas: Turismo, cultural y ciudadanos. Amigos Museos 2011, 2011, 11-14.

2. ABC Economía. Exceltur: El sector Turístico Crecerá un 3.2\% en 2017, Tras un Año 'Difícilmente Repetible'. 16 January 2017. Available online: http:/ / www.abc.es/economia/abci-excetur-sector-turistico-crecera-32por-ciento-2017-tras-dificilmente-repetible-201701161224_noticia.html (accessed on 12 November 2017).

3. Troitiño Vinuesa, M.A. Turismo, patrimonio y recuperación urbana en ciudades y conjuntos históricos. Patrim. Cult. Esp. 2012, 6, 147-164.

4. Bandarin, F. Introduction. Urban Conservation and the End of Planning. In Reconnecting the City: The Historic Urban Landscape Approach and the Future of Urban Heritage; Bandarin, F., Van Oers, R., Eds.; Wiley Blackwell: Chichester, UK, 2015; ISBN 9781118383988.

5. UNESCO Recommendation on the Historic Urban Landscape. Paris, 10 November 2011. Available online: http:/ / whc.unesco.org/uploads/activities/documents/activity-638-98.pdf (accessed on 11 October 2017).

6. Bandarín, F. From paradox to paradigm? Historic Urban Landscape as an urban conservation approach. In Managing Cultural Landscapes; Taylor, K., Lennon, J., Eds.; Routledge: New York, NY, USA, 2012; pp. 213-231. ISBN 9780415672245.

7. United Nation, Sustainable Development Goals. Available online: http:/ /www.un.org/sustainabledevelopment/ cities/ (accessed on 12 October 2017).

8. Quito Declaration on Sustainable Cities and Human Settlements for All. New Urban Agenda. Habitat III. 2016. Available online: http:/ / habitat3.org/wp-content/uploads/Habitat-III-New-Urban-Agenda-10September-2016.pdf (accessed on 14 October 2017).

9. ICOMOS. Charter for the Conservation of Historic Towns and Urban Areas (Washintong Charter 1987). Available online: https:/ / www.icomos.org/charters/towns_e.pdf (accessed on 20 October 2017).

10. ICOMOS. Australia ICOMOS Charter for Places of Cultural Significance (The Burra Charter, 2013). Available online: http:/ / australia.icomos.org/publications / charters/ (accessed on 20 October 2017). First developed by ICOMOS Australia in 1979 and subsequently updated (last update in 2013).

11. UNESCO. Managing Cultural World Heritage. Resources Manual; UNESCO, ICCROM, ICOMOS, IUCN: Paris, France, 2013; pp. 24-25. ISBN 9789230012236.

12. UNESCO General Assembly of States Parties. 10-11 October 2005. Resolution 15 GA 7. Available online: http:/ / whc.unesco.org/archive/2005/whc05-15ga-inf7e.pdf (accessed on 20 October 2017).

13. O'Donnell, P. Historic Urban Landscape. A new UNESCO Tool for a Sustainable Future. In Conserving Cultural Landscapes. Challenges and New Directions; Taylor, K., St. Clair, A., Mitchell, N., Eds.; Routledge: New York, NY, USA, 2015; pp. 163-181. ISBN 9780415744058.

14. Actas de la Conferencia General. Reunión 38 ${ }^{a}$. París, 3-18 de Noviembre 2015; UNESCO: Paris, France, 2016; Available online: http:/ / unesdoc.unesco.org/images/0024/002433/243325s.pdf (accessed on 18 October 2017).

15. Araoz, G. Preserving heritage places under a new paradigm. J. Cult. Heritage Manag. Sustain. Dev. 2011, 1, 55-60. [CrossRef] 
16. The HUL Guidebook. Managing Heritage in Dynamic and Constantly Changing Urban Environments; UNESCO, WHITECAP UNESCO, City of Ballarat. 2016. Available online: http:/ / historicurbanlandscape. com/themes/196/userfiles/download/2016/6/7/wirey5prpznidqx.pdf (accessed on 2 October 2017).

17. GO-HUL Global Observatory on th Historic Urban Landscape. Available online: https://go-hul.com (accessed on 2 November 2017).

18. Wijesuriya, G. Living Heritage: A Summary. Annexe 1; ICCROM: Roma, Italy, 2015; Available online: http:/ / docplayer.net/54811472-Living-heritage-a-summary.html (accessed on 18 January 2017).

19. Court, S.; Wijesuriya, G. People-Centred Approaches to the Conservation of Cultural Heritage: Living Heritage; ICCROM: Roma, Italy, 2015; Available online: https:/ /www.iccrom.org/sites/default/files/PCA_Annexe-2. pdf (accessed on 20 November 2017).

20. Wijesuriya, G. Conservation in Context. In Proceedings of the International Conference on 'Conservation and Preservation-Interaction between Theory and Practice, in Memoriam Alois Riegl (1858-1905)'; Falser, M.S., Lipp, W., Tomaszewski, A., Eds.; Edizioni Polistampa: Firenze, Italy, 2010; pp. 233-248. ISBN 9788859607465.

21. ICOMOS. Draft of Delhi Declaration (NA 2017-12-06). 2017. Available online: http://icomosga2017.org (accessed on 18 December 2017).

22. Junta de Andalucía. El Paisaje Histórico Urbano en las Ciudades Históricas Patrimonio Mundial: Indicadores Para su Conservación y Gestión; Fernández-Baca, R., Salmerón Escobar, P., Sanz, N., Eds.; Junta de Andalucía: Sevilla, Spain, 2009; ISBN 9788482668826.

23. Asworth, G.J.; Tunbridge, J.E. The Tourist-Historic City; Belhaven Press: London, UK, 1990; ISBN 9781852930226.

24. All Periodic Reports. Available online: http:/ / whc.unesco.org/en/list/ (accessed on 15 September 2017).

25. UNESCO-WHC. Frequently Asked Questions. Available online: https://whc.unesco.org/uploads/pages / documents/document-355-1.pdf (accessed on 14 April 2018).

26. UNESCO-WHC Periodic Reporting Handbook for Site Managers. 2012. Available online: https://whc. unesco.org/uploads/pages/documents/document-153-6.pdf (accessed on 14 April 2018).

27. Final Report on the Results of the Second Cycle of the Periodic Reporting Exercise for the Europe Region and Action Plan; Report for Europe, WHC-15/39.COM/10A; UNESCO-WHC: París, France, 2015; Available online: https:/ / whc.unesco.org/en/eur-na/ (accessed on 14 April 2018).

28. UNESCO-WHC. Periodic Reporting Reflection Survey. A Summary of Results. 2016. Available online: https://whc.unesco.org/document/140525 (accessed on 14 April 2018).

29. UNESCO. Culture Urban Future; UNESCO: Paris, France, 2016; pp. 17-22. ISBN 9789231001703.

30. El País. Turismo. Las Plazas en Pisos Turísticos Superan a las de Hoteles por Primera vez. 24 May 2017. Available online: https://elpais.com/economia/2017/05/24/actualidad/1495627776_282170.html (accessed on 12 November 2017).

31. El Periódico. La Inquietud de los Barceloneses por el Turismo y la Vivienda se Dispara. 6 November 2017. Available online: http:/ / www.elperiodico.com/es/barcelona/20171106/barcelona-turismo-problema-masgrave-6404679 (accessed on 12 November 2017).

32. BBC. Turismofobia: Barcelona y Otras Ciudades en Pie de Guerra Contra el Turismo de Masas. 1 June 2017. Available online: http:/ / www.bbc.com/mundo/noticias-40107507 (accessed on 12 November 2017).

33. Instituto Nacional de Estadística, Spain (INE). Proyecciones de Población 2016-2066. Nota de Prensa. Available online: http:/ / www.ine.es/prensa/np994.pdf (accessed on 20 December 2017).

34. Troitiño Vinuesa, M.A. Turismo y desarrollo sostenibles en ciudades históricas. Ería 1998, 47, $211-228$.

35. Troitiño Vinuesa, M.A. Turismo y sostenibilidad: La Alhambra y Granada. An. Geogr. Univ. Complut. 2000, 20, 337-396.

36. Troitiño Vinuesa, M.A. La protección, recuperación y revitalización funcional de los centros históricos. In Ciudades, Arquitectura y Espacio Urbano; Capel, H., Coord, Eds.; Instituto Cajamar: Almería, Spain, 2003; pp. 131-160. ISBN 8495531-12-7.

37. Troitiño Vinuesa, M.A.; Troitiño Torralba, L. Turismo cultural y destinos patrimoniales en España: Situación actual y retos de futuro. In Turismo Cultural en Ciudades Patrimonio de la Humanidad; Mondejar Jiménez, A., Gómez Borja, M., Coords, Eds.; Universidad de Castilla-La Mancha: Cuenca, Spain, 2009; pp. 15-51. ISBN 9788484275862.

38. Troitiño Vinuesa, M.A.; De la Calle Vaquero, M.; García Hernández, M. Las actividades turístico-recreativas en los Planes de Gestión de sitios Patrimonio Mundial: El caso de Aranjuez, Paisaje Cultural de la Humanidad. Cuad. Tur. 2011, 27, 901-923. 
39. García Hernandez, M. Turismo y Conjuntos Monumentales: Capacidad de Acogida y Gestión de Flujos de Visitantes; Tirant lo Blanch: Valencia, Spain, 2003; ISBN 9788484427575.

40. Lara, F.; López, T. El turismo como motor de desarrollo económico en ciudades patrimonio de la humanidad. Pasos Rev. Tur. Patrim. Cult. 2004, 2, 243-256. [CrossRef]

41. De la Calle Vaquero, M. La Ciudad Histórica Como Destino Turístico; Ariel: Barcelona, Spain, 2002; ISBN 9788434467989.

42. Romero Moragas, C. Ciudad, cultura y turismo: Calidad y autenticidad. Revista PH 2001, 36, 100-109.

43. García Cuetos, M.P. Humilde Condición. El Patrimonio Cultural y la Conservación de su Autenticidad; Trea: Gijón, Spain, 2009; ISBN 9788497044509.

44. Prats, LL. La mercantilización del patrimonio: Entre la economía turística y las representaciones identitarias. Revista PH 2006, 58, 72-80.

45. Fernández-Baca, R.; Fernández Cacho, S.; Ortega Palomo, G. La gestión del paisaje histórico urbano en Ciudades Patrimonio Mundial. Metodología de análisis, seguimiento y evaluación. In El Paisaje Histórico Urbano en las Ciudades Patrimonio Mundial. Indicadores Para su Conservación y Gestión II. Criterios, Metodología y Estudios Aplicados; Fernández-Baca, R., Salmerón Escobar, P., Sanz, N., Eds.; Junta de Andalucía: Sevilla, Spain, 2011; pp. 55-122. ISBN 9788499590424.

46. García Henandez, M.; De la Calle Vaquero, M.; Yubero, C. Cultural heritage and Urban Tourism: Historic City Centres under Pressure. Sustainability 2017, 9, 1346. [CrossRef]

47. Wiiliam, P.W.; Gill, A. Carring Capacity Managment in Tourism Setting: A Tourism Growth Management Process; OCLC: 850062397; Center for Tourism Policy and Research, Simon Fraser University: Vancouver, BC, Canada, 1991.

48. Junta de Andalucía. El Paisaje Histórico Urbano en las Ciudades Históricas Patrimonio Mundial: Indicadores Para su Conservación y Gestión II. Criterios, Metodología y Estudios Aplicados; Fernández-Baca, R., Salmerón Escobar, P., Sanz, N., Eds.; Junta de Andalucía: Sevilla, Spain, 2011; ISBN 9788499590424.

49. Source: Own Elaboration Based on Data from the Municipal Register of Inhabitants of Toledo. Available online: https:/ / www.toledo.es/servicios-municipales/padron-de-habitantes/ (accessed on 12 November 2017).

50. Source: Own Elaboration Based on Data from the Municipal Register of Inhabitants of Cuenca. Available online: http: / / www.cuenca.es (accessed on 12 November 2017).

51. Eldiario.es Castilla-La Mancha. Vivir en un Casco Histórico Patrimonio de la Humanidad: Menos Servicios y Menos Gente. 30 July 2017. Available online: http:/ / www.eldiario.es/clm/Vivir-patrimonio-humanidadservicios-souvenirs_0_668433373.html (accessed on 28 December 2017).

52. Martínez, L.C.; Molina, I.; Delgado, J.M. Procesos demográficos y urbanos en la transformación espacial de la ciudad de Ávila. Investig. Geogr. 2014, 62, 163-179.

53. Source: Municipal Register of Inhabitants of Avila and Sources of Historic Heritage Service of the Council of Ávila. Available online: http:/ / www.avila.es (accessed on 12 November 2017).

54. Plan de Gestión. Ciudad Patrimonio Mundial "La Ciudad Antigua de Ávila y sus Iglesias Extramuros"; Dirección General de Patrimonio Cultural, Consejería de Cultura y Turismo Junta de Castilla y León, Ayuntamiento de Ávila: Ávila, Spain, 2013; Available online: https:/ / patrimoniocultural.jcyl.es/web/jcyl/ PatrimonioCultural/es/Plantilla100/1284258511072/_/_/_ (accessed on 10 November 2017).

55. Source: Own Elaboration Based on Data from the Municipal Register of Inhabitants of Segovia. Available online: http://www.segovia.es/index.php/mod.pags/mem.listado/relcategoria.2406/chk. ca7449cd46af19ed9194232484a54b13 (accessed on 28 November 2017).

56. Source: Own Elaboration Based on Data from the Municipal Register of Inhabitants of Santiago de Compostela and Instituto Nacional de Estadística, INE. Available online: http://www.avila.es and http:/ / www.ine.es (accessed on 28 November 2017).

57. Source: Own Elaboration Based on Data from the Municipal Register of Inhabitants of La Laguna. Available online: http:/ / www.aytolalaguna.com (accessed on 12 November 2017).

58. Plan de Movilidad de La Laguna, Fase I: Información y Análisis de la Situación Actual de la Movilidad del Municipio. La Laguna, Spain. 2010. Available online: http://www.gerenciaurbanismo.com/ gerencia/GERENCIA/published/DEFAULT/K2\%20-\%20Plan\%20de\%20Movilidad/01_FASE\%20I/01_ CARACTERIZACION\%20SOCIOECONOMICA/MEMORIA.pdf (accessed on 10 April 2018).

59. Ciudades Patrimonio de la Humanidad. Ciudades + Humanas. Patrimonio + Social; Ministerio Educación Cultura y Deporte, Ciudades Patrimonio de la Humanidad: Madrid, Spain, 2015. 
60. Europa Press. España Sella 2017 Como Segunda Potencia Turística Mundial Superando a EEUU y Solo por Detrás de Francia. 10 January 2018. Available online: http:/ / www.europapress.es/turismo/nacional/noticiaespana-bate-record-82-millones-turistas-internacionales-2017-superaria-eeuu-20180110211537.html (accessed on 10 January 2018).

61. Operational Guidelines for the Implementation of the World Heritage Convention. WHC.17/01 12 July 2017. UNESCO-World Heritage Centre, 2017. Available online: http://whc.unesco.org/en/guidelines/ (accessed on 22 November 2017).

62. European Landscape Convention. Florence, 20.X.2000; Concil of Euroope: Strasbourg, France, 2000; Available online: https:/ / www.coe.int/en/web/conventions/full-list/-/conventions/rms/0900001680080621 (accessed on 12 November 2017).

63. García Fernández, J. Estudios Sobre el Derecho del Patrimonio Histórico; Colegio de Registradores de la Propiedad y Mercantiles de España: Madrid, Spain, 2008; pp. 213-231. ISBN 9788496782358.

64. Decree of 9 March 1940, declaring Historical and Artistic Monuments the cities of Santiago and Toledo. Boletín Oficial del Estado 18 April 1940. pp. 1657-2658. Available online: https:/ / boe.es/datos/pdfs/BOE/ /1940/109/A02657-02658.pdf (accessed on 12 December 2017).

65. Memoria del Consorcio de Toledo 2016; Consorcio de la Ciudad de Toledo: Toledo, Spain, 2017; Available online: https:/ / issuu.com/consorciodetoledo/docs/memoria_consorcio_2016web (accessed on 30 December 2017).

66. Sistema de Información Patrimonial. Consorcio de Santiago, Instituto Geográfico Nacional. Available online: http:/ / sip.consorciodesantiago.org/SIPWeb/\#p=0 (accessed on 15 November 2017).

67. Guidebook on Community Involvement in Urban Heritage; Göttler, M.; Ripp, M. (Eds.) City of Regensburg, Organisation of World Heritage Cities (OWHC): Regensburg, Germany, 2017; Available online: https://www.ovpm.org/en/regional_secretariats/news/owhc-guidebook-2017-communityinvolvement-heritage-management (accessed on 28 November 2017).

68. Tosun, C.; Timothy, D.J. Arguments for Community Participation in the Tourism Development Process. J. Tour. Stud. 2003, 14, 2-15.

69. Zhang, Y.; Cole, S.T.; Chancellor, C.H. Residents' Preferences for Involvement in Tourism Development and Influences from Individual Profiles. Tour. Plan. Dev. 2013, 10, 267-284. [CrossRef]

70. Jordan, E.J.; Vogt, C.A.; Kruger, L.E.; Grewe, N. The interplay of governance, power and citizen participation in community tourism planning. J. Policy Res. Tour. Leis. Events 2013, 5, 270-288. [CrossRef]

71. Brown, J.; Hay-Edie, T. Engaging Local Communities in Stewardship of World Heritage. World Heritage Pap. 2014, 40, 1-117. Available online: http:/ / unesdoc.unesco.org/images/0023/002303/230372e.pdf (accessed on 28 December 2017).

72. Li, Y.; Hunter, C. Community involvement for sustainable heritage tourism: A conceptual model. J. Cult. Heritage Manag. Sustain. Dev. 2015, 5, 248-262. [CrossRef]

73. Taylor, K.; Cook, I. A Contemporary Guide to Cultural Mapping. An ASEAN Australia Perspective; Public Outreach and Civil Society Division: Jakarta, Indonesia, 2013; ISBN 9786027643130.

74. Lalana Soto, J.L. Las Zonas de Amortiguamiento. In Documentos 01. Centro Ciudades Patrimonio Mundial; Centro de Ciudades Patrimonio Mundial: Ávila, Spain, 2010; pp. 1-16.

75. Plan Nacional de Paisaje Cultural. Ministerio de Educación, Cultura y Deporte, Instituto del Patrimonio Cultural de España. Available online: http:/ / www.mecd.gob.es/planes-nacionales/planes-nacionales / paisaje-cultural/categorias.html (accessed on 18 September 2017).

76. Lalana Soto, J.L. El Paisaje Urbano Histórico: Modas, paradigmas y olvidos. Ciudades 2011, 14, 15-28. Available online: https://dialnet.unirioja.es/servlet/articulo?codigo=3720255 (accessed on 12 September 2017). [CrossRef]

77. Azkarate, A.; Azpeitia, A. Paisajes Urbanos Históricos. ¿Paradigma o Subterfugio? In Alla Ricerca di un Passato Completo. Contributi in Onore di Gian Pietro Brogiolo per il suo Settantesimo Compleanno; Jurkovic, M., Chavarria, A., Eds.; University of Zagreb: Zagreb, Croatia, 2016; pp. 219-238. ISBN 9789536002924.

78. UNESCO. Joint Report on the Participation in the "Seminar on Control and Management of Urban Planning in Spanish World Heritage Cities", Aranjuez (Spain), 27-28 September 2007; WHC-08/32.COM/7B; UNESCO: París, France, 2008.

79. Plan Director de la Alhambra 2007-2020; Patronato de la Alhambra y el Generalife: Granada, Spain, 2010; ISBN 9788486827274. Available online: http:/ / www.alhambra-patronato.es/index.php/Plan-Director-2007-2020/ 803/0/ (accessed on 11 November 2017). 
80. Presentación Datos Estadísticos de la Actividad Cultural, Educativa y Turística 2016. Conjunto Monumental de La Alhambra y el Generalife; Patronato de la Alhambra y el Generalife, Conserjería de Cultura: Granada, Spain; Available online: http:/ / www.alhambra-patronato.es/fileadmin/pdf/visitas_guiadas/Balance_de_ Visitantes_2016.pdf (accessed on 12 January 2018).

81. Boughlala, F.; González, A.; López, P. Memoria de Actividades de la Agencia Albaicín 2016; Ayuntameinto de Granda, WHC: Granada, Spain, 2016; Available online: http:/ / www.albaicin-granada.com/estaticas/1249_ memoriaactividades2016a_albaicin.pdf (accessed on 12 May 2018).

82. Agencia Albaicín. Noticias. Albaicín y Sacromonte Impulsan un Innovador Espacio de Participación Ciudadana Para la Mejora y Avance de Estos Barrios. Available online: http:/ / www.albaicin-granada.com/ noticias.php?listEntrada=317 (accessed on 12 April 2018).

83. Libro Blanco de la Gestión del Patrimonio Histórico-Arqueológico del Grupo de Ciudades Patrimonio de la Humanidad de España. Grupo Ciudades Patrimonio de la Humanidad, Kultura, Ministerio de Educación, Cultura y Deporte. 2015. Available online: http:/ / www.ciudadespatrimonio.org/publicaciones/ 1427495607_LIBROBLANCO.pdf (accessed on 28 November 2017).

84. Plan de Gestión de la Ciudad Vieja de Salamanca: Actuaciones y Estrategias de Protección y Conservación del Bien Patrimonial y sus Componentes; Dirección General de Patrimonio Cultural, Consejería de Cultura y Turismo, Junta de Castilla y León, Ayuntamiento de Salamanca: Salamanca, Spain, 2017; Available online: http:/ / urbanismo.aytosalamanca.es/es/planeamientourbanistico/anuncio_0004 (accessed on 14 December 2017).

85. Plan de Gestión de la Ciudad Vieja de Salamanca. Ciudad Patrimonio Mundial. Documento de Sintesis; Dirección Geral. Patrimonio Cultural Junta de Castilla y León: León, Spain, 2013.

86. PEAHIS. Plan Especial de Áreas Históricas de Segovia; Ayuntamiento de Segovia: Segovia, Spain, 2015; Available online: http:/ / www.segovia.es/peahis/INICIO.html (accessed on 10 January 2018).

(C) 2018 by the author. Licensee MDPI, Basel, Switzerland. This article is an open access article distributed under the terms and conditions of the Creative Commons Attribution (CC BY) license (http:/ / creativecommons.org/licenses/by/4.0/). 